\title{
Accumulation of DOC in Low Phosphate Low Chlorophyll (LPLC) area: is it related to higher production under high $\mathrm{N}: \mathrm{P}$ ratio?
}

\author{
R. Mauriac, T. Moutin, and M. Baklouti \\ INSU-CNRS, Laboratoire d'Océanographie Physique et Biogéochimique, UMR 6535, Centre d'Océanologie de Marseille, \\ Aix Marseille Université, France
}

Received: 29 July 2010 - Published in Biogeosciences Discuss.: 23 September 2010

Revised: 15 January 2011 - Accepted: 1 February 2011 - Published: 15 April 2011

\begin{abstract}
The biogeochemistry of carbon and nutrients $(\mathrm{N}, \mathrm{P})$ in the surface layer of the ocean strongly depends on the complex interactions between primary producers (phytoplankton) and remineralizers (heterotrophic bacteria). To understand how these interactions impact the overall DOC dynamics in the surface layer of the Mediterranean Sea, we implemented, using Eco3M (Ecological Mechanistic Modular Modelling tool), a multi-element model with a mechanistic description of primary production. We studied the model steady state results under various nutrient conditions and fixed cell abundances. By doing so, we show how the bottom up control of osmotrophs growth can impact the overall DOC dynamics in the system. Based on our set of parameters, the biogeochemical characteristics displayed by the model appear realistic when compared to literature data for the Mediterranean basin. Differences in DOC dynamics between $\mathrm{N}$ and $\mathrm{P}$ limited systems in the model, lead to the conclusion that the unusually high $\mathrm{N}: \mathrm{P}$ ratio of the Mediterranean Sea may favour the uncoupling between growth and carbon production leading to higher DOC accumulation compared to systems with lower $\mathrm{N}: \mathrm{P}$ ratio.
\end{abstract}

\section{Introduction}

During summer, the surface layer of the Mediterranean Sea is a stratified Low Phosphate Low Chlorophyll (LPLC) system (Moutin et al., 2008). The high nitrate to phosphate ratio observed below the euphotic zone (Krom et al., 1991) and the significant response of primary and bacterial production in bioassay experiments have suggested that both phytoplankton and heterotrophic bacteria are P-limited or NP-

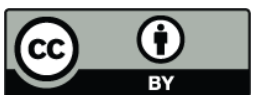

Correspondence to: R. Mauriac (romain.mauriac@univmed.fr) co-limited (Thingstad et al., 1998, 2005). Unfortunately, inorganic nutrients concentrations are often close to or below the detection limit in this layer and elemental content of osmotrophs is rarely quantified directly on board. This makes the understanding of the coupling between carbon, nutrients and growth at the cell level difficult to assess. On short time scales, the observed response in bioassay experiments is likely to be a relatively complex phenomenon involving cell physiology for uptake, as well as, storage of limiting and near limiting resources. This is regarded as a key issue when trying to understand the coupling between nutrient and carbon in the eupohtic zone. To overcome this issue, theoretical mechanistic models provide a good counterpart to in situ measurements. A Numerical model based on P-limitation of both bacterial and phytoplankton growth has successfully described qualitatively some of the observed features of the surface water of the Mediterranean Sea (Thingstad, 2005). However, for heterotrophic bacteria, enrichment in both organic carbon and nutrients systematically leads to a stronger response compared to experiments with nutrients alone (Wambeke et al., 2002). This means that interaction between heterotrophic bacteria and phytoplankton is probably more complex than simple competition for inorganic nutrients and that the organic carbon production rate and the lability of the different available carbon sources may also play a role in the observed DOC dynamics. In this study, we investigate a simple dynamical mechanistic model that includes both competition for inorganic nutrients and commensalism (through DOC exudation and re-mineralization) between pico-phytoplankton and heterotrophic bacteria. During summer, a tight balance between growth limitation by nutrients and control of cell abundances by predation results in relatively stable populations of both group of osmotrophs (Magazzu and Decembrini, 1995; Christaki et al., 2001). In this context, we chose to look at the steady state results assuming constant cell abundance and a conservative amount

Published by Copernicus Publications on behalf of the European Geosciences Union. 


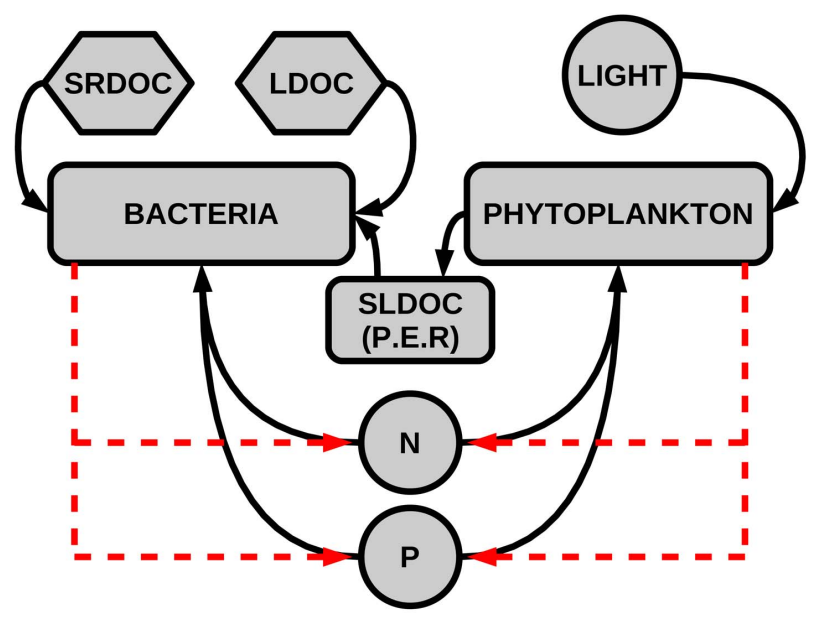

Fig. 1. Diagram representing a simplified system of competition and commensalism between bacteria and phytoplankton. Both groups are competing for nutrients $(\mathrm{N}, \mathrm{P})$ but while phytoplankton relies on light to produce carbon, bacteria uses three organic carbon sources that originated either from photosynthetic extracellular release (PER) or from grazing and mortality. PER was considered a semi-labile DOC source (SLDOC). $40 \%$ of DOC from grazing and mortality was considered semi-refractory (SRDOC) and 10\% was considered as labile (LDOC).

of nutrients. This steady state system can impact the overall DOC dynamics in different ways but ultimately depends on the balance between DOC production through mortality and exudation and DOC consumption through heterotrophic bacterial activities. Our steady state results suggest that although the system appears balanced or net heterotrophic during summer, the ratio of inorganic nitrogen to inorganic phosphate could have an impact on the observed DOC accumulation in the surface layer of LPLC areas over seasonal time scales.

\section{Model description}

\subsection{Overview}

During summer, the offshore surface water of the Mediterranean Sea is characterized by low levels of production, small organisms and stable stratification. In addition, variation in cellular abundance of phytoplankton is relatively small suggesting a state of particular equilibrium for this functional group (Magazzu and Decembrini, 1995). For heterotrophic bacteria, the close coupling between bacterial production and predation by higher trophic levels, suggests a similar pattern (Christaki et al., 2001). Based on these considerations, we assumed a constant cell abundance for both groups. During this period of stable stratification, the system relies mostly on regenerated nutrients due to internal recycling of organic matter (Moutin and Raimbault, 2002). Hence, we assumed that the system could be assimilated to a steady

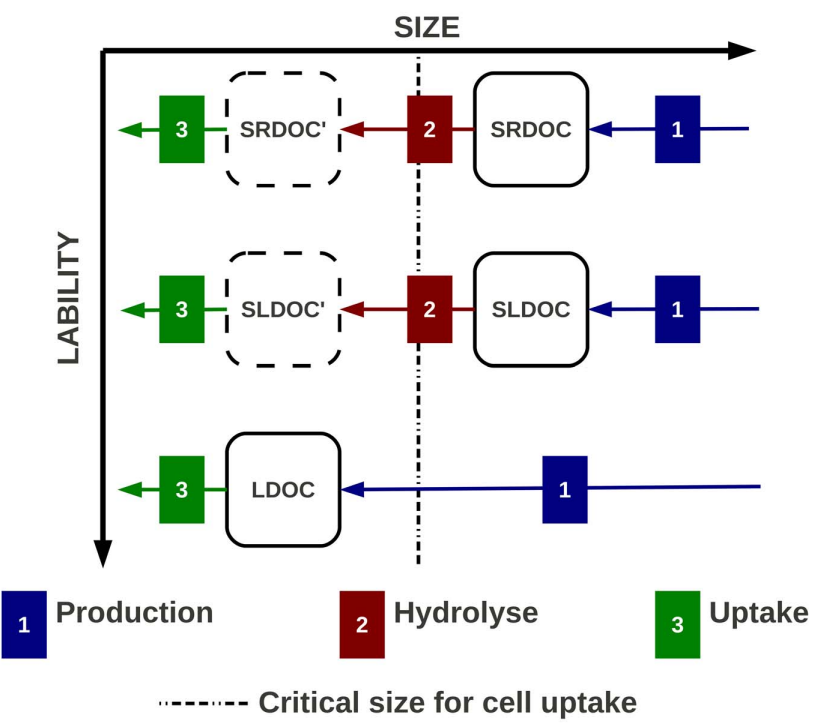

Fig. 2. Diagram representing dissolved organic matter in the model. Each pool is discriminated based on size and lability assumptions. Two pools (SLDOC and SRDOC) are considered similar in size and above the critical size of particle that can pass through bacterial cell wall (thus they need an hydrolysis step before being assimilated). LDOC on the other hand is considered to be directly assimilable. In terms of lability, each DOC pool is associated with an assimilation efficiency of $0.7,0.5$ and 0.3 for LDOC, SLDOC and SRDOC respectively.

state system where loss of nutrients is compensated by remineralization of organic compounds, making dissolved organic nitrogen (DON) and phosphate (DOP) implicit in our model. The conceptual model (Fig. 1) that comes from our steady state assumptions includes two living compartments (picophytoplankton and heterotrophic bacteria), two inorganic compartments $(\mathrm{N}$ and $\mathrm{P})$ and three distinct more or less labile DOC pools that supply the Bacterial Carbon Demand (BCD). LDOC, SLDOC and SRDOC represent the three detritic compartments in the model. SRDOC and SLDOC are assumed to have similar sizes above the critical size for direct assimilation, an hydrolysis step is thus required (Fig. 2). Different assimilation efficiencies were associated with each pool. SLDOC and SRDOC are thus similar in size but differ in terms of lability. LDOC was associated with the highest assimilation efficiency (0.7) and with a size below the critical size for direct cell uptake, no hydrolysis required prior to assimilation. DOC production in the model is the result of two distinct processes. It is either supplied by exudation of carbon by phytoplankton (photosynthetic extracellular release (PER)) or via grazing and mortality. The DOC supplied through grazing and mortality represented $50 \%$ of phytoplankton and bacterial mortality as suggested by Hagstrom et al. (1988). The other half is supposed to be transferred to higher trophic level and thus lost for the system. In the model, $40 \%$ of DOC originating from grazing and mortality 
is assumed to be a semi refractory form (SRDOC) and $10 \%$ is present as the most labile form (LDOC). This fractionation between LDOC and SRDOC intends to represent the release of compounds of different labilities during cell lysis and sloppy feeding processes. The $10 \%$ attributed to the LDOC pool in the model is also close to the fraction of total DOC that is considered to be most labile (Sondergaard and Middelboe, 1995). We did not explicitly represent the labile fraction of DOP and DON in our model. We assume that the labile part was instantaneously remineralized into the inorganic form resulting in algal-bacterial competition for both N (Kirchman, 1994; Bronk et al., 2007), and P (Thingstad et al., 1997; Moutin and Raimbault, 2002; Thingstad, 2005).

\subsubsection{State equations}

\section{Phytoplankton}

$$
\begin{aligned}
& \frac{d \varphi}{d t}=f_{\varphi}^{\mu} \varphi-f_{\varphi}^{m} \varphi \\
& \frac{d \varphi_{C}}{d t}=f_{n r}^{\mathrm{PP}} h_{\varphi}^{Q_{C}} \varphi-f_{\varphi}^{\mathrm{resp}} \varphi-f_{\varphi}^{m} Q_{C}^{\varphi} \varphi \\
& \frac{d \varphi_{N}}{d t}=f_{\varphi}^{\mathrm{upt}_{N}} h_{\varphi}^{Q_{N}} \varphi-f_{\varphi}^{m} Q_{N}^{\varphi} \varphi \\
& \frac{d \varphi_{P}}{d t}=f_{\varphi}^{\mathrm{upt}_{P}} h_{\varphi}^{Q_{P}} \varphi-f_{\varphi}^{m} Q_{P}^{\varphi} \varphi \\
& \frac{d \varphi_{\mathrm{Chl}}}{d t}=f^{\mathrm{PChl}} \varphi_{N}-f_{\varphi}^{\mu} Q_{\mathrm{Chl}}^{\varphi} \varphi
\end{aligned}
$$

\section{Bacteria}

$$
\begin{aligned}
& \frac{d \beta}{d t}=f_{\beta}^{\mu} \beta-f_{\beta}^{m} \beta \\
& \frac{d \beta_{C}}{d t}=\left(f_{\beta}^{\text {upt }_{\text {LDOC }}}+f_{\beta}^{\text {upt }_{\text {SLDOC }}}+f_{\beta}^{\text {upt }_{\text {SRDOC }}}\right) h_{\beta}^{Q_{C}} \beta \\
& -f_{\beta}^{\text {resp }} \beta-f_{\beta}^{m} Q_{C}^{\beta} \beta \\
& \frac{d \beta_{N}}{d t}=f_{\beta}^{\text {upt }_{N}} h_{\beta}^{Q_{N}} \beta-f_{\beta}^{m} Q_{N}^{\beta} \beta \\
& \frac{d \beta_{P}}{d t}=f_{\beta}^{\text {upt }_{P}} h_{\beta}^{Q_{P}} \beta-f_{\beta}^{m} Q_{P}^{\beta} \beta
\end{aligned}
$$

\section{Dissolved organic carbon}

$$
\begin{aligned}
& \frac{\mathrm{dLDOC}}{d t}=\omega_{5}\left(f_{\varphi}^{m} Q_{C}^{\varphi} \varphi+f_{\beta}^{m} Q_{C}^{\beta} \beta_{C}\right) \\
& -f_{\beta}^{\mathrm{upt}_{\mathrm{LDOC}}} h_{\beta}^{Q_{C}} \beta \\
& \frac{\mathrm{dSLDOC}}{d t}=f_{n r}^{\mathrm{PP}}\left(1-h_{\varphi}^{Q_{C}}\right) \varphi-f_{\beta}^{\mathrm{upt}_{\mathrm{SLDOC}}} h_{\beta}^{Q_{C}} \beta \\
& \frac{\mathrm{dSRDOC}}{d t}=\omega_{6}\left(f_{\varphi}^{m} Q_{C}^{\varphi} \varphi+f_{\beta}^{m} Q_{C}^{\beta} \beta_{C}\right) \\
& -f_{\beta}^{\mathrm{upt}_{\text {SRDOC }}} h_{\beta}^{Q_{C}} \beta
\end{aligned}
$$

\section{Nutrients}

$$
\begin{aligned}
& \frac{d N}{d t}=f_{\varphi}^{m} Q_{N}^{\varphi} \varphi+f_{\beta}^{m} Q_{N}^{\beta} \beta-f_{\beta}^{\mathrm{upt}_{N}} h_{\beta}^{Q_{N}} \beta \\
& -f_{\varphi}^{\mathrm{upt}_{N}} h_{\varphi}^{Q_{N}} \varphi \\
& \frac{d P}{d t}=f_{\varphi}^{m} Q_{P}^{\varphi} \varphi+f_{\beta}^{m} Q_{P}^{\beta} \beta-f_{\beta}^{\mathrm{upt}_{P}} h_{\beta}^{Q_{P}} \beta \\
& -f_{\varphi}^{\mathrm{upt}_{P}} h_{\varphi}^{Q_{P}} \varphi
\end{aligned}
$$

Our system is mathematically described with 14 state variables (Table 1 and Eqs. 1-14) and 5 biogeochemical processes, namely growth, mortality, nutrient uptake, primary production and respiration (cf. Sects. 2.2-2.5). Bacterial and phytoplankton are described in terms of cellular abundance and $\mathrm{C}, \mathrm{N}, \mathrm{P}$ biomass, and an additional state variable representing phytoplankton chlorophyll biomass is used (Sect. 2.4). For phytoplankton, we assume that the population was composed solely of synechococcus cells, a genus known to dominate in the surface layer of the Mediterranean Sea during the summer period (Vaulot et al., 1996). All the state variables, process functions, and parameters used in the model are defined in Tables 1 to 5 .

\subsection{Intracellular quota and growth}

The model is based on the assumption that there are a minimum $\left(Q_{X}^{\min }\right)$ and maximum $\left(Q_{X}^{\max }\right)$ intracellular content for each element $X$ among $(\mathrm{C}, \mathrm{N}, \mathrm{P}) . Q_{X}^{\min }$ can be interpreted as the amount of element $X$ used in cellular structure and machinery and everything else can be seen as storage for future growth. Since Droop and his work on vitamin B12 (Droop, 1968), this concept has been widely used, especially to simulate change in organisms' stoichiometry (Klausmeier et al., 2008). We therefore used the classical Droop formulation (Eq. 15) combined with the Leibig's law of the minimum to describe growth rate.

$f^{\mu}=\bar{\mu} \min \left[\left(1-\frac{Q_{C}^{\min }}{Q_{C}}\right) ;\left(\left(1-\frac{Q_{N}^{\min }}{Q_{N}}\right) ;\left(1-\frac{Q_{P}^{\min }}{Q_{P}}\right)\right]\right.$

In this formulation, $Q_{X}$ represents the actual cell content for a given element $\mathrm{X}$, and $\bar{\mu}$ the maximum theoretical growth rate of the organism. It should be noted that imposing an explicit maximum intracellular quota with the Droop formulation implies that $\bar{\mu}$ is never achieved. In Eq. (15), the maximum achievable growth rate $(\hat{\mu})$ is controlled by the $Q_{X}^{\max }$ value of the element for which the organism possess the smallest storage capacity. Since we assumed that for each element $X, Q_{X}^{\max }$ is 2.5 times greater than $Q_{X}^{\min }$, the maximum achievable growth rate $\hat{\mu}$ is equal to $0.6 \bar{\mu}$. Concerning the factor 2.5 between $Q_{X}^{\min }$ and $Q_{X}^{\max }$, if we assume that an individual cell needs at least to double its biomass before being able to divide into two cells, then $Q_{X}^{\max }=2 Q_{X}^{\min }$ appears as a minimum value for $Q_{X}^{\max }$. The value 2.5 which has been used in the present study is a compromise between 
Table 1. Model's state variables.

\begin{tabular}{|c|c|c|}
\hline Symbol & Definition & Unit \\
\hline \multicolumn{3}{|c|}{ Phytoplankton } \\
\hline$\varphi$ & Phytoplankton abundance & cell m ${ }^{-3}$ \\
\hline$Q_{C}^{\varphi}$ & Phytoplankton carbon content & mol cell $^{-1}$ \\
\hline$Q_{N}^{\breve{\varphi}}$ & Phytoplankton nitrogen content & mol cell $^{-1}$ \\
\hline$Q_{P}^{\varphi}$ & Phytoplankton phosphate content & mol cell $^{-1}$ \\
\hline$Q_{\mathrm{Chl}}^{\varphi}$ & Phytoplankton Chlorophyll content & $\mathrm{g} \mathrm{cell}^{-1}$ \\
\hline$\varphi_{C}$ & Phytoplankton carbon biomass & $\mathrm{mol} \mathrm{m}^{-3}$ \\
\hline$\varphi_{N}$ & Phytoplankton nitrogen biomass & $\mathrm{mol} \mathrm{m}^{-3}$ \\
\hline$\varphi_{P}$ & Phytoplankton phosphate biomass & $\mathrm{mol} \mathrm{m}^{-3}$ \\
\hline$\varphi_{\mathrm{Chl}}$ & Phytoplankton Chlorophyll biomass & $\mathrm{g} \mathrm{m}^{-3}$ \\
\hline \multicolumn{3}{|c|}{ Heterotrophic bacteria } \\
\hline$\beta$ & Bacteria abundance & cell $\mathrm{m}^{-3}$ \\
\hline$Q_{C}^{\beta}$ & Bacteria carbon content & mol cell $^{-1}$ \\
\hline$Q_{N}^{\beta}$ & Bacteria nitrogen content & $\mathrm{mol} \mathrm{cell}^{-1}$ \\
\hline$Q_{P}^{\beta}$ & Bacteria phosphate content & $\mathrm{mol} \mathrm{cell}^{-1}$ \\
\hline$\beta_{C}$ & Bacteria carbon biomass & $\mathrm{mol} \mathrm{m}^{-3}$ \\
\hline$\beta_{N}$ & Bacteria nitrogen biomass & $\mathrm{mol} \mathrm{m}^{-3}$ \\
\hline$\beta_{P}$ & Bacteria phosphate biomass & $\mathrm{mol} \mathrm{m}^{-3}$ \\
\hline \multicolumn{3}{|c|}{ Non-living } \\
\hline LDOC & Labile DOC concentration & $\mathrm{mol} \mathrm{m}^{-3}$ \\
\hline SLDOC & Semi-labile DOC concentration (PER) & $\mathrm{mol} \mathrm{m}^{-3}$ \\
\hline SRDOC & Semi-refractory DOC concentration & $\mathrm{mol} \mathrm{m}^{-3}$ \\
\hline$N$ & Inorganic nitrogen concentration & $\mathrm{mol} \mathrm{m}^{-3}$ \\
\hline$P$ & Inorganic phosphate concentration & $\mathrm{mol} \mathrm{m}^{-3}$ \\
\hline
\end{tabular}

(i) the fact that an element can be stored in excess of what is required for one cell division, (ii) the fact that our values should be within the range of reported values in the literature (Mauriac et al., 2011). Also, we assumed that $\bar{\mu}$ is the same regardless of the organisms considered. We can suspect this assumption is not always verified (Goldman and McCarthy, 1978; Terry et al., 1985), but to keep the model as simple as possible, we have used it in our simulations. Hence, for phytoplankton and bacteria, the maximum growth rate $\bar{\mu}$ is set to $2.310^{-5} \mathrm{~s}^{-1}\left(2 \mathrm{~d}^{-1}\right)$, thus $\hat{\mu}$ is equal to $1.3910^{-5} \mathrm{~s}^{-1}$ $\left(1.2 \mathrm{~d}^{-1}\right)$.

The minimum $\mathrm{P}$ content $Q_{P}^{\min }$ for bacteria is set to $1.6110^{-17} \mathrm{~mol} \mathrm{cell}^{-1}\left(0.50 \mathrm{fgP}\right.$ cell $\left.^{-1}\right)$ which is close to values found for aquatic bacteria (Fagerbakke et al., 1996; Gundersen et al., 2002; Lovdal et al., 2008). Using an optimal C:N:P ratio of 50:10:1 (Fagerbakke et al., 1996), minimum C content is $8.110^{-16} \mathrm{~mol} \mathrm{cell}^{-1}\left(9.68 \mathrm{fgC} \mathrm{cell}^{-1}\right)$ which seems acceptable for small oceanic bacteria (Fukuda et al., 1998; Gundersen et al., 2002). The minimum nitrogen content of $1.6110^{-16} \mathrm{~mol} \mathrm{cell}^{-1}$ (2.26 fgN cell $\left.{ }^{-1}\right)$, resulting from the optimal ratio selected, is also close to published values for oceanic bacteria (Fukuda et al., 1998). For phytoplankton, the minimum $\mathrm{P}$ content is $6.410^{-17} \mathrm{~mol} \mathrm{cell}^{-1}$ $\left(2 \mathrm{fgP}\right.$ cell $\left.^{-1}\right)$. It is in the range of values found in the literature using both direct and indirect measurements (Ikeya et al., 1997; Heldal et al., 2003; Bertilsson et al., 2003). Using the redfield ratio as the optimal ratio (C:N:P 106:16:1), the minimum carbon and nitrogen content in phytoplankton cells are respectively set to $6.810^{-15} \mathrm{~mol} \mathrm{cell}^{-1}\left(82 \mathrm{fgC} \mathrm{cell}^{-1}\right.$ and $10^{-15} \mathrm{~mol} \mathrm{cell}^{-1}\left(14.5 \mathrm{fgN} \mathrm{cell}^{-1}\right)$.

\subsection{Uptake of nutrients}

To describe the gross uptake rate of nutrients, the MichaelisMenten relationship was chosen for its simplicity (Eq. 16). A feedback from internal cellular status to mediate the net uptake rate is in the form of a quota function (Eq. 17) (Lehman et al., 1975).

$$
\begin{aligned}
& f^{\text {upt }_{X}}=V_{X}^{\max } \frac{[X]}{[X]+K_{X}} \\
& h^{Q_{X}}=\frac{Q_{X}^{\max }-Q_{X}}{Q_{X}^{\max }-Q_{X}^{\min }}
\end{aligned}
$$

$[X]$ represents the concentration of an element $X(\mathrm{~N}$ or $\mathrm{P})$ taken up by phytoplankton and bacteria. $V_{X}^{\max }$ and $K_{X}$ are assumed constant in the model and represent the uptake parameters one would obtain from nutrient starved organisms (e.g maximum potential uptake rate). This maximum potential uptake rate is associated with a maximum theoretical affinity $\alpha_{\max }$, which represents the volume of water cleared for nutrients per unit of biomass per hour (Healey, 1980):

$\alpha_{\max }=\frac{V_{X}^{\max }}{K_{X} Q_{X}^{\min }}$

This equation shows that the maximum affinity of a given organism is the ratio between its uptake ability (how fast an organism can take up an element) and its requirements for growth (how much of this element is needed to produce a new cell). Therefore Eq. (18) express the organism competitiveness. Saying that bacteria are more competitive than phytoplankton is the same as saying that $\alpha_{\max }^{\beta}>\alpha_{\max }^{\varphi}$. For a spherical cell, and assuming that all the molecules reaching the cell through molecular diffusion are captured, the theoretical expression for $\alpha_{\max }$ has also been given by (Thingstad and Rassoulzadegan, 1999):

$\alpha_{\max }=\frac{3 \mathrm{D}}{\gamma r^{2}}$

Here, $D$ is the diffusion coefficient for nutrient, $\gamma$ is the minimum internal nutrient concentration $\left(\mathrm{mol} \mu \mathrm{m}^{-3}\right)$ or the so called conversion factor, and $r$ is the cell radius. $\gamma$ can also be expressed as the ratio of $Q_{X}^{\min }$ with the cell volume $\left(\frac{4}{3} \pi r^{3}\right)$ and Eq. (19) can be rearranged as follows:

$\alpha_{\max }=\frac{4 \pi D r}{Q_{X}^{\min }}$ 
Table 2. Model's functions.

\begin{tabular}{|c|c|c|}
\hline Symbol & Definition & Unit \\
\hline \multicolumn{3}{|c|}{ Phytoplankton } \\
\hline$f_{\varphi}^{\mu}$ & Phytoplankton specific growth rate & $\mathrm{s}^{-1}$ \\
\hline$f_{\varphi}^{m}$ & Phytoplankton specific mortality rate & $s^{-1}$ \\
\hline$f_{n r}^{\mathrm{PP}}$ & Gross primary production (nutrient repleted) & mol cell ${ }^{-1} \mathrm{~s}^{-1}$ \\
\hline$f^{\mathrm{PChl}}$ & Chlorophyll production rate & $\mathrm{g} \mathrm{mol}^{-1} \mathrm{~s}^{-1}$ \\
\hline$f_{\varphi}^{\mathrm{resp}}$ & Phytoplankton respiration rate & mol cell ${ }^{-1} \mathrm{~s}^{-1}$ \\
\hline$f_{\varphi}^{\text {upt }}$ & Phytoplankton nitrogen uptake rate (nutrient starved) & mol cell ${ }^{-1} \mathrm{~s}^{-1}$ \\
\hline$f_{\varphi}^{\text {uptP }}$ & Phytoplankton phosphate uptake rate (nutrient starved) & mol cell ${ }^{-1} \mathrm{~s}^{-1}$ \\
\hline$h_{\varphi}^{Q_{C}}$ & Phytoplankton quota function for carbon & - \\
\hline$h_{\varphi}^{Q_{N}}$ & Phytoplankton quota function for nitrogen & - \\
\hline$h_{\varphi}^{Q_{P}}$ & Phytoplankton quota function for phosphate & - \\
\hline \multicolumn{3}{|c|}{ Heterotrophic bacteria } \\
\hline$f_{\beta}^{\mu}$ & Bacteria specific growth rate & $\mathrm{s}^{-1}$ \\
\hline$f_{\beta}^{m}$ & Bacteria specific mortality rate & $\mathrm{s}^{-1}$ \\
\hline$f_{\beta}^{\text {upt }} t_{\mathrm{LDOC}}$ & Bacteria LDOC uptake rate (nutrient starved) & mol cell ${ }^{-1} \mathrm{~s}^{-1}$ \\
\hline$f_{\beta}^{\text {upt SLDOC }}$ & Bacteria SLDOC uptake rate (nutrient starved) & mol cell ${ }^{-1} \mathrm{~s}^{-1}$ \\
\hline$f_{\beta}^{\text {upt }}{ }_{\text {SRDOC }}$ & Bacteria SRDOC uptake rate (nutrient starved) & mol cell $^{-1} \mathrm{~s}^{-1}$ \\
\hline$f_{\beta}^{\text {resp }}$ & Bacteria respiration rate & mol cell ${ }^{-1} \mathrm{~s}^{-1}$ \\
\hline$f_{\beta}^{\text {upt }_{\mathrm{N}}}$ & Bacteria nitrogen uptake rate (nutrient starved) & mol cell ${ }^{-1} \mathrm{~s}^{-1}$ \\
\hline$f_{\beta}^{\text {uptp }}$ & Bacteria phosphate uptake rate (nutrient starved) & mol cell ${ }^{-1} \mathrm{~s}^{-1}$ \\
\hline$h_{\beta}^{Q_{C}}$ & Bacteria quota function for carbon & - \\
\hline$h_{\beta}^{Q_{N}}$ & Bacteria quota function for nitrogen & - \\
\hline$h_{\beta}^{Q_{P}}$ & Bacteria quota function for phosphate & - \\
\hline
\end{tabular}

Table 3. Miscellaneous model parameters.

\begin{tabular}{llll}
\hline Symbol & Definition & Units & Values \\
\hline Diffusion rate & & & \\
$D_{\text {NUT }}$ & Molecular diffusion coefficient for nutrients & $\mathrm{m}^{2} \mathrm{~s}^{-1}$ & $110^{-9}$ \\
$D_{\text {LDOC }}$ & Molecular diffusion coefficient for LDOC & $\mathrm{m}^{2} \mathrm{~s}^{-1}$ & $310^{-10}$ \\
$D_{\text {SLDOC(SRDOC) }}$ & Molecular diffusion coefficient for SLDOC and SRDOC & $\mathrm{m}^{2} \mathrm{~s}^{-1}$ & $610^{-11}$ \\
Mortality & & & \\
$\omega_{5}$ & Fraction of mortality returning as LDOC & - & 0.1 \\
$\omega_{6}$ & Fraction of mortality returnning as SRDOC & - & 0.4 \\
\hline
\end{tabular}

Using Eq. (18) and Eq. (20), we obtain the following relationship:

$$
\frac{V_{X}^{\max }}{K_{X}}=4 \pi D r
$$

Eq. (21), conveys the idea that, under extremely low nutrient concentrations, diffusion is the limiting step in the uptake process. In this study, $D$ was set to $10^{-9} \mathrm{~m}^{2} \mathrm{~s}^{-1}$, an intermediate value commonly used for ions in seawater (Yuan-Hui and Gregory, 1974), and $r$ was set to 0.5 and $0.18 \mu \mathrm{m}$ for phytoplankton and bacteria respectively (Tables 4 and 5). $V^{\max }$ was chosen based on literature values for uptake of phosphate (Ikeya et al., 1997; Fu et al., 2006) and the half-saturation constant $K_{P}$ was derived from Eq. (21). Assuming that the diffusion coefficients for $\mathrm{N}$ and $\mathrm{P}$ are the same, and accounting for Eq. (21) we can write: 
Table 4. Model parameters for phytoplankton.

\begin{tabular}{|c|c|c|c|}
\hline Symbol & Definition & Units & Values \\
\hline \multicolumn{4}{|c|}{ Intracellular content and growth } \\
\hline $\bar{\mu}$ & maximum specific growth rate & $s^{-1}$ & $2.310^{-5}$ \\
\hline$Q_{P}^{\min }$ & minimum phosphate content & mol cell $^{-1}$ & $6.410^{-17}$ \\
\hline$Q_{P}^{\max }$ & maximum phosphate content & mol cell $^{-1}$ & $2.5 Q_{P}^{\min }$ \\
\hline$Q_{N}^{\min }$ & minimum nitrogen content & mol cell $^{-1}$ & $16 Q_{P}^{\mathrm{min}}$ \\
\hline$Q_{N}^{\max }$ & maximum nitrogen content & mol cell $^{-1}$ & $2.5 Q_{N}^{\min }$ \\
\hline$Q_{C}^{\min }$ & minimum carbon content & mol cell $^{-1}$ & $106 Q_{P}^{\min }$ \\
\hline$Q_{C}^{\max }$ & maximum carbon content & mol cell $^{-1}$ & $2.5 Q_{C}^{\mathrm{min}}$ \\
\hline \multicolumn{4}{|c|}{ Nutrient uptake } \\
\hline$r$ & Cell radius & $\mathrm{m}$ & $510^{-7}$ \\
\hline$\alpha_{P}$ & Affinity for phosphate & $\mathrm{m}^{3} \mathrm{~mol}^{-1} \mathrm{~s}^{-1}$ & 93 \\
\hline$\alpha_{N}$ & Affinty for nitrogen & $\mathrm{m}^{3} \mathrm{~mol}^{-1} \mathrm{~s}^{-1}$ & 5.8 \\
\hline$V_{N(P)}^{\max }$ & Maximum uptake rate for nutrients $(\mathrm{N} \& \mathrm{P})$ & mol cell ${ }^{-1} \mathrm{~s}^{-1}$ & $610^{-19}$ \\
\hline$K_{N(P)}$ & Half-saturation constant for nutrients uptake (N \& P) & $\mathrm{mol} \mathrm{m}^{-3}$ & $10^{-4}$ \\
\hline \multicolumn{4}{|c|}{ Photosynthesis and respiration } \\
\hline$\tau$ & Electron turnover-time in PSII & s & $2.510^{-3}$ \\
\hline$\sigma_{\mathrm{PSII}}$ & PSII cross section & $\mathrm{m}^{2} \mathrm{~J}^{-1}$ & 8 \\
\hline$k_{d}^{H}$ & Dimensionless rate of PSII damage & - & $4.510^{-8}$ \\
\hline$k_{r}^{a}$ & PSII repair rate & $\mathrm{s}^{-1}$ & $2.610^{-4}$ \\
\hline $\bar{a}^{*}$ & Mean Chl- $a$-specific absorption coefficient & $\mathrm{m}^{2} \mathrm{gChl}^{-1}$ & 37 \\
\hline$\phi_{\max }^{C}$ & Maximum quantum yield for carbon fixation & $\mathrm{molC} \mathrm{J}^{-1}$ & $110^{-7}$ \\
\hline$Q_{\mathrm{Chl} / \mathrm{N}}^{\max }$ & Maximum chlorophyll to nitrogen ratio & $\mathrm{gChl} \mathrm{molN}{ }^{-1}$ & 2 \\
\hline$\omega_{4}$ & Fraction of surplus $\mathrm{C}$ respired & $\mathrm{s}^{-1}$ & $2.8910^{-5}$ \\
\hline
\end{tabular}

$\frac{V_{N}^{\max }}{K_{N}}=\frac{V_{P}^{\max }}{K_{P}}$

Since we have found in several studies that the halfsaturation constants for $\mathrm{P}$ and $\mathrm{N}$ are not so different (Table 6 ), we therefore chose $K_{N}=K_{P}$ for the sake of simplicity. Combined with Eq. (22), this leads to $V_{N}^{\max }=V_{P}^{\max }$. We are aware that this is a simplification of reality but this simplification is not wholly unreasonable as it maintains a difference between the maximum affinity for $\mathrm{P}$ and the maximum affinity for $\mathrm{N}$ (by a factor 16 for phytoplankton and 10 for heterotrophic bacteria) similarly to what is reported in the litterature (cf. Riegman et al. (2000) and reference herein). Several studies have looked at the competition between phytoplankton and heterotrophic bacteria both for phosphate and nitrogen. Most of them show that heterotrophic bacteria are better competitors than phytoplankton (including picophytoplankton) for the acquisition of $\mathrm{N}$ and $\mathrm{P}$ at low concentrations (Kirchman, 1994; Joint et al., 2002; Grover, 2000; Drakare, 2002) and this is in agreement with the uptake parameters used in this work.

\subsection{Photosynthesis, chlorophyll production and autotrophic respiration}

The model uses a mechanistic formulation for photosynthesis and chlorophyll production. The basic idea of the photosynthesis model (Han, 2002) is that the reaction center of PSII can be found in three different states, namely open (and therefore reactive for photosynthesis), close (that means already occupied) or photodamaged. In this model, the primary production rate is therefore proportional to the number of PSII in the open state. The chlorophyll model relies on the fact that the rate at which chlorophyll is produced depends on the nitrogen status of the cell (Baklouti et al., 2006a). A thorough investigation of the associated mathematical formulations given in Eqs. (23) and (24) and their sensitivity to parameter values can be found in the two papers by Baklouti et al. (2006a,b). These formulations were chosen for their mechanistic underlyings and the fact that all parameters are measurable. In Eq. (24), we chose to scale the production rate to the maximum growth rate to allow chlorophyll synthesis in the case where intracellular $\mathrm{N}$ content is greater than $Q_{N}^{\min }$ but $N$ uptake rate is zero. 
Table 5. Model's parameters for heterotrophic bacteria.

\begin{tabular}{|c|c|c|c|}
\hline Symbol & Definition & Units & Values \\
\hline \multicolumn{4}{|c|}{$\begin{array}{l}\text { Heterotrophic bacteria } \\
\text { Intracellular content and growth }\end{array}$} \\
\hline $\begin{array}{l}\bar{\mu} \\
Q_{P}^{\min } \\
Q_{P}^{\max } \\
Q_{N}^{\min } \\
Q_{N}^{\max } \\
Q_{C}^{\min } \\
Q_{C}^{\max }\end{array}$ & $\begin{array}{l}\text { maximum specific growth rate } \\
\text { minimum phosphate content } \\
\text { maximum phosphate content } \\
\text { minimum nitrogen content } \\
\text { maximum nitrogen content } \\
\text { minimum carbon content } \\
\text { maximum carbon content }\end{array}$ & $\begin{array}{l}\mathrm{s}^{-1} \\
\mathrm{~mol} \mathrm{cell}^{-1} \\
\mathrm{~mol} \mathrm{cell}^{-1} \\
\mathrm{~mol} \mathrm{cell}^{-1} \\
\mathrm{~mol} \mathrm{cell}^{-1} \\
\text { mol cell }^{-1} \\
\text { mol cell }^{-1}\end{array}$ & $\begin{array}{l}2.310^{-5} \\
1.6110^{-17} \\
2.5 Q_{P}^{\min } \\
10 Q_{P}^{\min } \\
2.5 Q_{N}^{\min } \\
50 Q_{P}^{\min } \\
2.5 Q_{C}^{\min }\end{array}$ \\
\hline \multicolumn{4}{|l|}{ Nutrient uptake } \\
\hline $\begin{array}{l}r \\
\alpha_{\max }^{P} \\
\alpha_{\max }^{N} \\
V_{N(P)}^{\max } \\
K_{N(P)}\end{array}$ & $\begin{array}{l}\text { Cell radius } \\
\text { Maximum affinity for phosphate } \\
\text { Maximum affinity for nitrogen } \\
\text { Maximum uptake rate for nutrients (N \& P) } \\
\text { Half-saturation constant for nutrients uptake (N \& P) }\end{array}$ & $\begin{array}{l}\mathrm{m} \\
\mathrm{m}^{3} \mathrm{~mol}^{-1} \mathrm{~s}^{-1} \\
\mathrm{~m}^{3} \mathrm{~mol}^{-1} \mathrm{~s}^{-1} \\
\mathrm{~mol} \mathrm{cell}^{-1} \mathrm{~s}^{-1} \\
\mathrm{~mol} \mathrm{~m}^{-3}\end{array}$ & $\begin{array}{l}1.8 \cdot 10^{-7} \\
140 \\
14 \\
910^{-20} \\
410^{-5}\end{array}$ \\
\hline \multicolumn{4}{|c|}{ DOC uptake and respiration } \\
\hline $\begin{array}{l}\alpha_{\text {LDOC }} \\
\alpha_{\text {SLDOC }} \\
\alpha_{\text {SRDOC }} \\
V_{\text {LDOC }}^{\max } \\
V_{\text {SLDOC(SRDOC) }}^{\max }\end{array}$ & $\begin{array}{l}\text { Maximum affinity for LDOC } \\
\text { Maximum affinity for SLDOC } \\
\text { Maximum affinity for SRDOC } \\
\text { Maximum uptake rate for LDOC } \\
\text { Maximum uptake rate for SLDOC }\end{array}$ & $\begin{array}{l}\mathrm{m}^{3} \mathrm{~mol}^{-1} \mathrm{~s}^{-1} \\
\mathrm{~m}^{3} \mathrm{~mol}^{-1} \mathrm{~s}^{-1} \\
\mathrm{~m}^{3} \mathrm{~mol}^{-1} \mathrm{~s}^{-1} \\
\mathrm{~mol} \mathrm{cell}^{-1} \cdot \mathrm{s}^{-1} \\
\mathrm{~mol} \mathrm{cell}\end{array}$ & $\begin{array}{l}1.1 \\
0.15 \\
0.09 \\
510^{-20} \\
2.510^{-20}\end{array}$ \\
\hline$K_{\mathrm{LDOC}}$ & Half-saturation constant for LDOC & $\mathrm{mol} \mathrm{m}^{-3}$ & $410^{-5}$ \\
\hline$K_{\text {SLDOC(SRDOC) }}$ & Half-saturation constant for SLDOC & $\mathrm{mol} \mathrm{m}^{-3}$ & $10^{-4}$ \\
\hline$\omega_{1}$ & Efficiency of LDOC uptake & - & 0.7 \\
\hline$\omega_{2}$ & Efficiency of SLDOC uptake & - & 0.5 \\
\hline$\omega_{3}$ & Efficiency of SRDOC uptake & - & 0.3 \\
\hline
\end{tabular}

Table 6. Half saturation constants for $\mathrm{N}$ and $\mathrm{P}$ found in literature for small phytoplankton

\begin{tabular}{lll}
\hline$K_{N}$ & $K_{P}$ & Reference \\
\hline $\mathrm{mol} \mathrm{m}^{-3}$ & $\mathrm{~mol} \mathrm{~m}^{-3}$ & \\
\hline $810^{-5}$ & $5.110^{-5}$ & Lovdal (2007) \\
$1.8-2.410^{-4}$ & $3.4-4.410^{-4}$ & Riegman et al. (2000) \\
& $2-410^{-4}$ & Fu et al. (2006) \\
& $4-1010^{-5}$ & Ikeya et al. (1997) \\
\hline
\end{tabular}

$f_{n r}^{\mathrm{PP}}=\frac{\phi_{\max }^{C} \bar{a}^{*} E Q_{\mathrm{Chl} / \mathrm{C}}^{\varphi}}{1+\sigma_{\mathrm{PSII}} E \tau+\left(k_{d}^{H} / k_{r}\right)\left(\sigma_{\mathrm{PSII}} E\right)^{2} \tau} Q_{C}^{\varphi}$

$f^{\mathrm{PChl}}=\frac{\bar{\mu}_{\varphi}\left(Q_{\mathrm{Ch} / \mathrm{N}}^{\varphi}\right)_{\max } f_{n r}^{\mathrm{PP}}}{\bar{a}^{*} \phi_{\max }^{C} Q_{\mathrm{Chl} / \mathrm{C}}^{\varphi} E} \frac{1-Q_{\mathrm{Chl} / \mathrm{N}}^{\varphi} /\left(Q_{\mathrm{Ch} / \mathrm{N}}^{\varphi}\right)_{\max }}{\left(1-Q_{\mathrm{Ch} / \mathrm{N}}^{\varphi} /\left(Q_{\mathrm{Ch} / \mathrm{N}}^{\varphi}\right)_{\max }\right)+0.05}$
In Eqs. (23) and (24), $\phi_{\max }^{C}$ represents the maximum quantum yield for carbon fixation, $\bar{a}^{*}$, the mean $\mathrm{Chl}$ a specific absorption coefficient, $E$, the irradiance, $Q_{\mathrm{Chl} / \mathrm{C}}^{i}$ the chlorophyll to carbon ratio, $\sigma_{\text {PSII }}$, the PSII cross section, $\tau$, the electron turnover time, $k_{d}^{H}$, the PSII damage rate, $k_{r}$, the PSII repair rate and $\left(Q_{\mathrm{Chl} / \mathrm{N}}^{i}\right)_{\max }$ the maximum chlorophyll to nitrogen ratio. Parameters were chosen to stay within the range of published values for phytoplankton (Yentsch and Vaccaro, 1958; Claustre et al., 2005). In the model, phytoplankton respiration is described by a "maintenance" cost associated with the excess carbon present in osmotrophic cells (see Thingstad (1987) for more detail concerning the term "maintenance").

$f_{\phi}^{\text {resp }}=\left(Q_{C}-Q_{C}^{\min }\right) \omega_{4}$

One aspect is that respiration rate will increase with increasing carbon intracellular content and this conveys the idea that respiration rate may be higher during the day, a feature that has been observed in natural communities (Weger et al., 1989). 

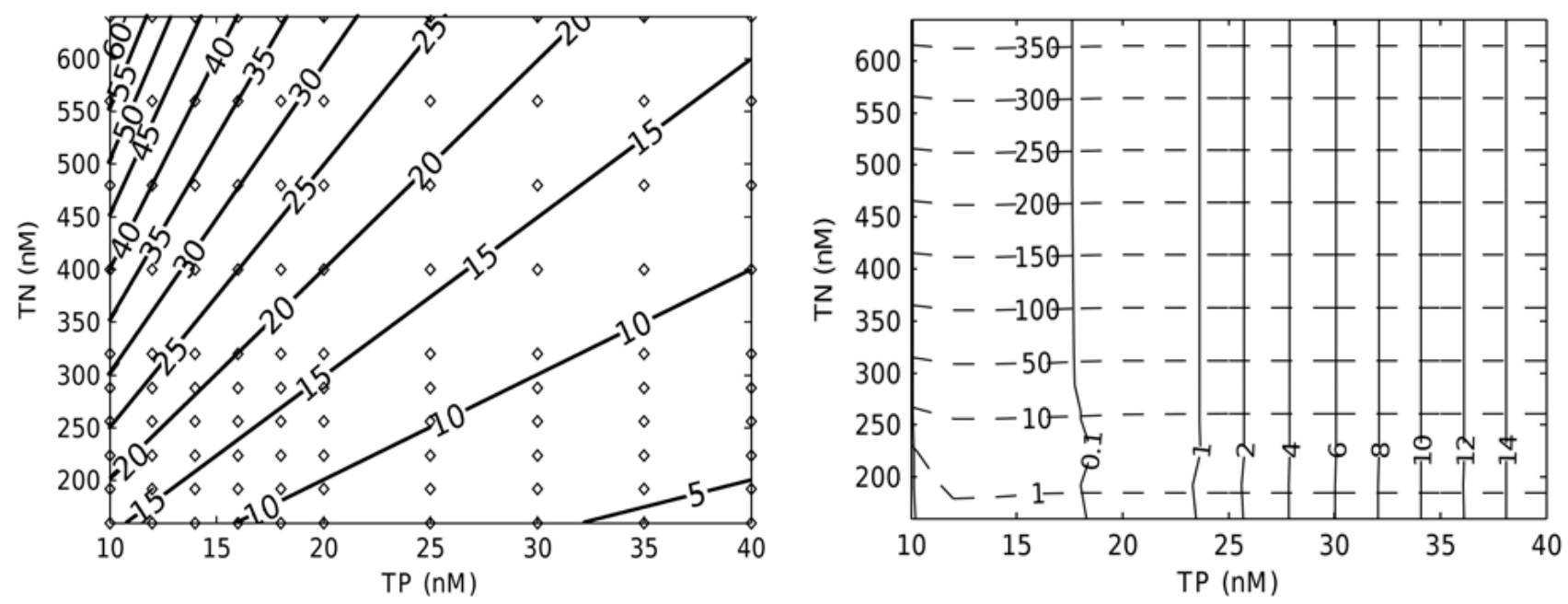

Fig. 3. (a) Range of total nitrogen (TN) and total phosphate (TP) concentrations tested with the model (diamonds markers represent the TN $\mathrm{TP}$ values tested in the different simulations and isolines represent the TN to TP ratio). (b) Inorganic nutrient concentrations at steady state in $\mathrm{nM}$ as a function of $\mathrm{TN}$ and $\mathrm{TP}$ (dashed lines represent inorganic nitrogen and solid lines inorganic phosphate).

\subsection{DOC uptake and respiration by bacteria}

Since SRDOC and SLDOC are larger in size than LDOC, these compounds need to be hydrolyzed before being assimilated by bacteria. However, we assumed that the products of the hydrolysis of SLDOC and SRDOC (denoted SLDOC' and SRDOC' in Fig. 2) are not LDOC but molecules of lower benefit for heterotrophic bacteria. In other words, the net budget between the carbon assimilated and the carbon respired is different for each DOC compartment. The net budget correspond to the parameters $\omega_{1}, \omega_{2}$ and $\omega_{3}$ in Table 5 (for example, for SRDOC only $30 \%$ of the gross SRDOC uptake can be stored within the cell, assuming that the remaining $70 \%$ is lost through respiration). While LDOC and SRDOC are produced through mortality processes, SLDOC comes from phytoplankton exudation (PER), which is often described as an overflow mechanism (Bjornsen, 1988). We further assumed that SLDOC (PER), which is mainly composed of carbohydrate chains (Myklestad, 1995), was less costly to transform into bacterial biomass than most of the DOC associated with mortality processes (SRDOC). For DOC uptake we used the same Michaelis-Menten equation as for nutrients (16). $V_{X}^{\max }$ and $K_{X}$ values for uptake of LDOC, SLDOC and SRDOC are chosen so that maximum affinity constants are one and two orders of magnitude lower than for inorganic nutrients. It allows us to take into account the larger size and thus lower diffusion rate of these molecules as well as the longer hydrolyse step require before bacteria can assimilate these compounds. If we consider glucose as a proxy of LDOC, then we are left with a wide range of values for both $K s$ and $V^{\max }$ (Schut et al. (1993) and reference within). Since we are interested in describing the uptake rate of an organisms strongly C-limited, we chose our $K s$ values for LDOC in the lower range of reported values $K_{\mathrm{LDOC}}=40$ $\mathrm{nM}$. Assuming a diffusion rate of $310^{-10} \mathrm{~m}^{2} \mathrm{~s}^{-1}$ (Nimer et al. (2003)), the resulting $V^{\max }$ based on Eq. (22) is $510^{-20} \mathrm{~mol} \mathrm{cell}^{-1} \mathrm{~s}^{-1}\left(0.18 \mathrm{fmol} \mathrm{cell}^{-1} \mathrm{~h}^{-1}\right)$. For SLDOC and SRDOC, we assume that the $V^{\max }$ was lower than for LDOC (assuming the hydrolysis step as the limiting step). We therefore set their $V^{\max }$ to half the value chosen for LDOC. We also tried to take into account the slower diffusion rate of these larger molecules by reducing the diffusion coefficient to $610^{-11} \mathrm{~m}^{2} \mathrm{~s}^{-1}$. Our choices is thus an extrapolation based on literature values for diffusion coefficient and uptake kinetics of labile DOC compounds such as glucose. We scaled SLDOC and SRDOC uptake kinetics based on the previous consideration. Based on the parameters chosen for SRDOC, SLDOC and LDOC, bacterial growth efficiency (BGE) cannot exceed 0.7 and could in theory reach zero when growth rate is null. The fact that BGE will vary with substrate supply and inorganic nutrient availability without exceeding 0.7 and the fact that bacteria may not grow at the same rate depending on the carbon source concur with in-situ observations (Middelboe and Sondergaard, 1993; del Giorgio and Cole, 1998). For heterotrophic bacteria the resulting respiration rate based on cost for DOC acquisition is:

$$
\begin{aligned}
& f_{\beta}^{\text {resp }}=\left(1-\omega_{1}\right) f_{\beta}^{\text {upt }_{\text {LDOC }}}+\left(1-\omega_{2}\right) f_{\beta}^{\text {upt }_{\text {SLDOC }}} \\
& +\left(1-\omega_{3}\right) f_{\beta}^{\text {upt }_{\text {SRDOC }}}
\end{aligned}
$$

This choice allows two types of carbon limitation, either limitation by availability (when DOC resource is low) or limitation by lability (when DOC acquisition is costly) both cases resulting in a low bacterial growth rate. 


\section{Simulations set up}

To describe the day/night cycle, the model was run with a given light regime described by the following equation:

$E=E_{\max } e^{(1.5 \cos (2 \pi t / 86400)-1)}$

Where $E_{\max }$ represents the irradiance at noon under the surface $\left(\mathrm{W} \mathrm{m}^{-2}\right)$ and $t$ the time in seconds. Since we set the mortality rate equal to the cellular growth rate at all time, cellular abundance is always constant and was fixed to $510^{8}$ cell $^{-1}$ and $2.510^{7}$ cell $1^{-1}$ for bacteria and phytoplankton respectively. These values are in the range of literature values for bacteria (Robarts et al., 1996; Lemee et al., 2002; Tanaka and Rassoulzadegan, 2004) and phytoplankton (Wambeke et al., 2001; Christaki et al., 2002; Tanaka and Rassoulzadegan, 2002; Siokou-Frangou et al., 2010) in the western Mediterranean basin. In addition, they allow the ratio of bacteria to phytoplankton carbon biomass to range between 0.12 and 0.94 which is consistent with the in-situ observations for the Mediterranean Sea (Pedros-Alio et al., 1999). At the beginning of each simulation, organisms are at their minimum intracellular content for all elements, $\mathrm{Chl}$ :C is set to $0.25 \mathrm{gChl} \mathrm{molC}^{-1}$ and DOC compartments are set to zero. Each simulation was run for 100 days with a fix amount of nitrogen and phosphate until a steady state regime was reached for both elements.

\section{Results}

The best way to interpret the results of our simulations is to consider that the model solves the mass balance equations for given growth conditions. The model gives an estimate of the $\mathrm{C}, \mathrm{N}, \mathrm{P}$ fluxes under various growth conditions assuming constant cell abundances. This is achieved by considering the sum of living and non living $\mathrm{N}$ and $\mathrm{P}$, which is denoted TN and TP, as conservative. By doing so we highlight the potential bottom up effect that $\mathrm{N}$ and $\mathrm{P}$ could have on the cycling of carbon in the system. The carbon budget in the model is inferred from the balance between carbon production through primary production, grazing or mortality and carbon respiration which depends on the cellular C-content of phytoplankton and on the efficiency at which heterotrophic bacteria assimilate DOC.

\subsection{Environmental conditions, growth and nutrient uptake}

We ran the model for a given range of total nitrogen (TN) and total phosphate (TP) values, from 160 to $640 \mathrm{nM}$ for $\mathrm{TN}$ and from 10 to $40 \mathrm{nM}$ for TP (Fig. 3a). The resulting TN:TP ratio range from 5 to 60 and represents N-limited as well as P-limited environments (Fig. 4a and 4b). Within the range of $\mathrm{TN}$ and $\mathrm{TP}$ used in this study, inorganic nutrient concentrations obtained at steady state range from 0 to $15 \mathrm{nM}$ and from 0 to $370 \mathrm{nM}$ for phosphate and nitrogen respectively (Fig. 3b). These values are consistent with what is usually measured in the surface water of the Mediterranean Sea (Krom et al., 1992; Pujo-Pay et al., 2010). Under these conditions, phytoplankton growth rate ranges between 0 and $0.53 \mathrm{~d}^{-1}$ (Fig. 4a) and bacterial growth rate ranges between 0 and $0.5 \mathrm{~d}^{-1}$ (Fig. 4b). For phytoplankton, the maximum growth rate is found when nutrient concentrations are higher than $0.09 \mathrm{nM}$ and $2 \mathrm{nM}$ for phosphate and nitrogen respectively. In contrast, for heterotrophic bacteria the maximum growth rate is found for low $\mathrm{P}$ concentrations $(0.06$ to $0.08 \mathrm{nM}$ ) associated with relatively high $\mathrm{N}$ concentrations $(>10 \mathrm{nM})$. This particular feature for heterotrophic bacterial growth is the result of a higher affinity for phosphate associated with high DOC availability (Fig. 8) which in turn results from a high DOC exudation rate by phytoplankton (Fig. 6d). Nutrient uptake rates ranged from 0 to $6 \mathrm{nmol}^{-1} \mathrm{~d}^{-1}$ for $\mathrm{P}$ (Fig. 5b) and from 0 to $115 \mathrm{nmoll}^{-1} \mathrm{~d}^{-1}$ for $\mathrm{N}$ (Fig. 5a). Uptake of both elements show non-linear patterns with respect to environmental conditions. Uptake of inorganic nitrogen is maximum where bacterial growth rate is high. Under these conditions, the fraction of $\mathrm{N}$ uptake attributed to phytoplankton is below $25 \%$ (data not shown) and total inorganic $\mathrm{N}$ uptake is mainly attributable to heterotrophic bacteria. In the simulations where both phytoplankton and bacteria are P-limited ( $10 \mathrm{nM}<\mathrm{TP}<15 \mathrm{nM})$, an increase in $\mathrm{N}$ uptake is observed with increasing $\mathrm{P}$ availability (Fig. 5a) and an increasing fraction of the uptake is attributable to phytoplankton (from 17 to $25 \%$ (data not shown)). For TP values above $15 \mathrm{nM}, \mathrm{N}$ uptake rate tends to decrease (Fig. 5a) and this is mainly due to a decrease of bacterial uptake caused by an increasing C-limitation of heterotrophic bacterial growth (Fig. 4b). Concerning P uptake the pattern is slightly different. Two maximum uptake rates are found (Fig. 5b). The first one is found for TP values between 13 and $15 \mathrm{nM}$ and is associated with the high $\mathrm{N}$ uptake rate described above and thus is mainly attributable to heterotrophic bacteria (85\% of total Puptake (data not shown)). The second maximum is observed under low $\mathrm{N}$ conditions $(\mathrm{TN}<200 \mathrm{nM})$ and relatively high $\mathrm{P}$ conditions $(\mathrm{TP}>25 \mathrm{nM})$. Under these conditions, the fraction of $\mathrm{P}$ uptake attributed to phytoplankton is higher and represents 20 to $40 \%$ of total P uptake. We thus obtained similar P uptake rates for two completely different settings where phytoplankton could either be $\mathrm{P}$ or $\mathrm{N}$ limited and heterotrophic bacteria $\mathrm{P}$ or $\mathrm{C}$ limited. In Fig. 5d turnover of phosphate, which represents the inorganic $\mathrm{P}$ concentration divided by the $\mathrm{P}$ uptake rate at steady state, ranges from less than $0.25 \mathrm{~h}$ to more than $50 \mathrm{~h}$ and seems to increase linearly with inorganic phosphate concentrations. In contrast, it is poorly correlated to the $\mathrm{P}$ uptake rate, despite a slight shift under low $\mathrm{N}$ conditions where $\mathrm{P}$ uptake rate is maximum. This highlights the fact that under steady state conditions, turnover time of phosphate is much more sensitive to a change in nutrient concentrations than to a change in uptake rate. Finally, The uncoupling of $\mathrm{N}$ and $\mathrm{P}$ uptake in the model is highlighted by 

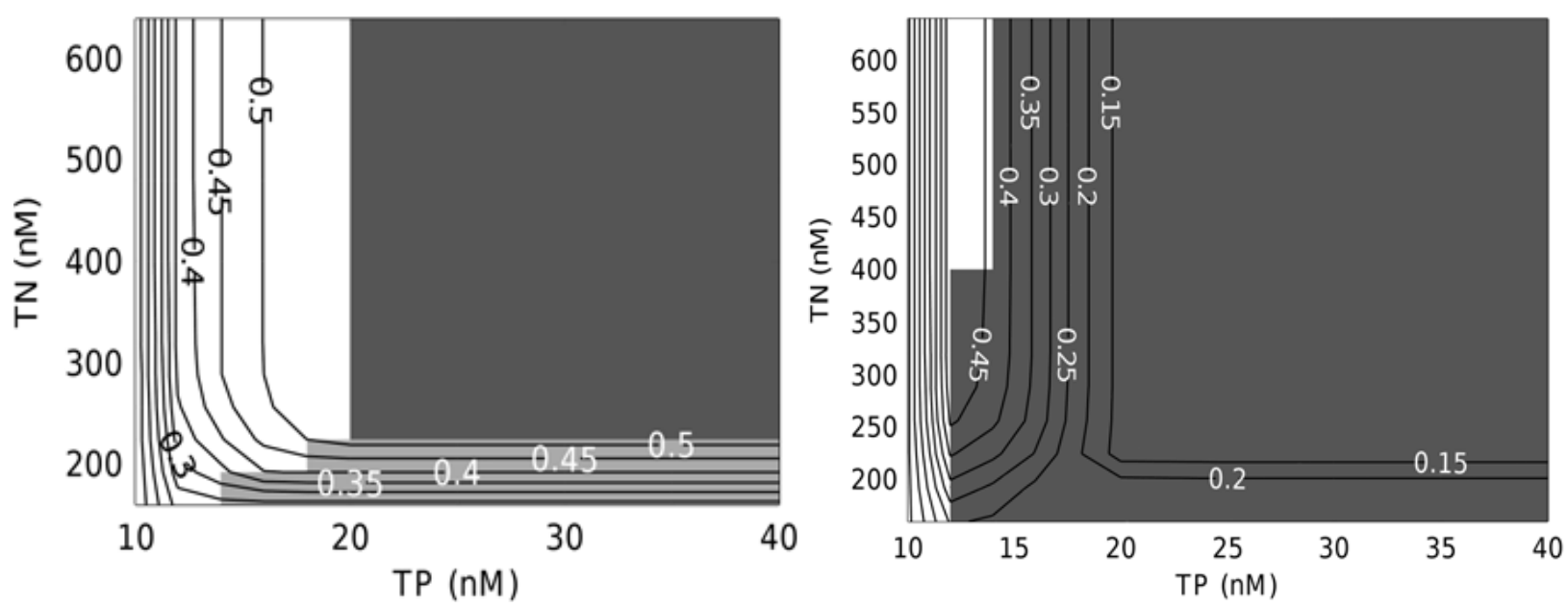

Fig. 4. Phytoplankton and bacterial growth rates per day as a function of total nitrogen (TN) and total phosphate (TP). Background color represents the element which is most limiting growth. (white color represents P-limitation, light grey, $\mathrm{N}$-limitation and dark grey $\mathrm{C}$-limitation).
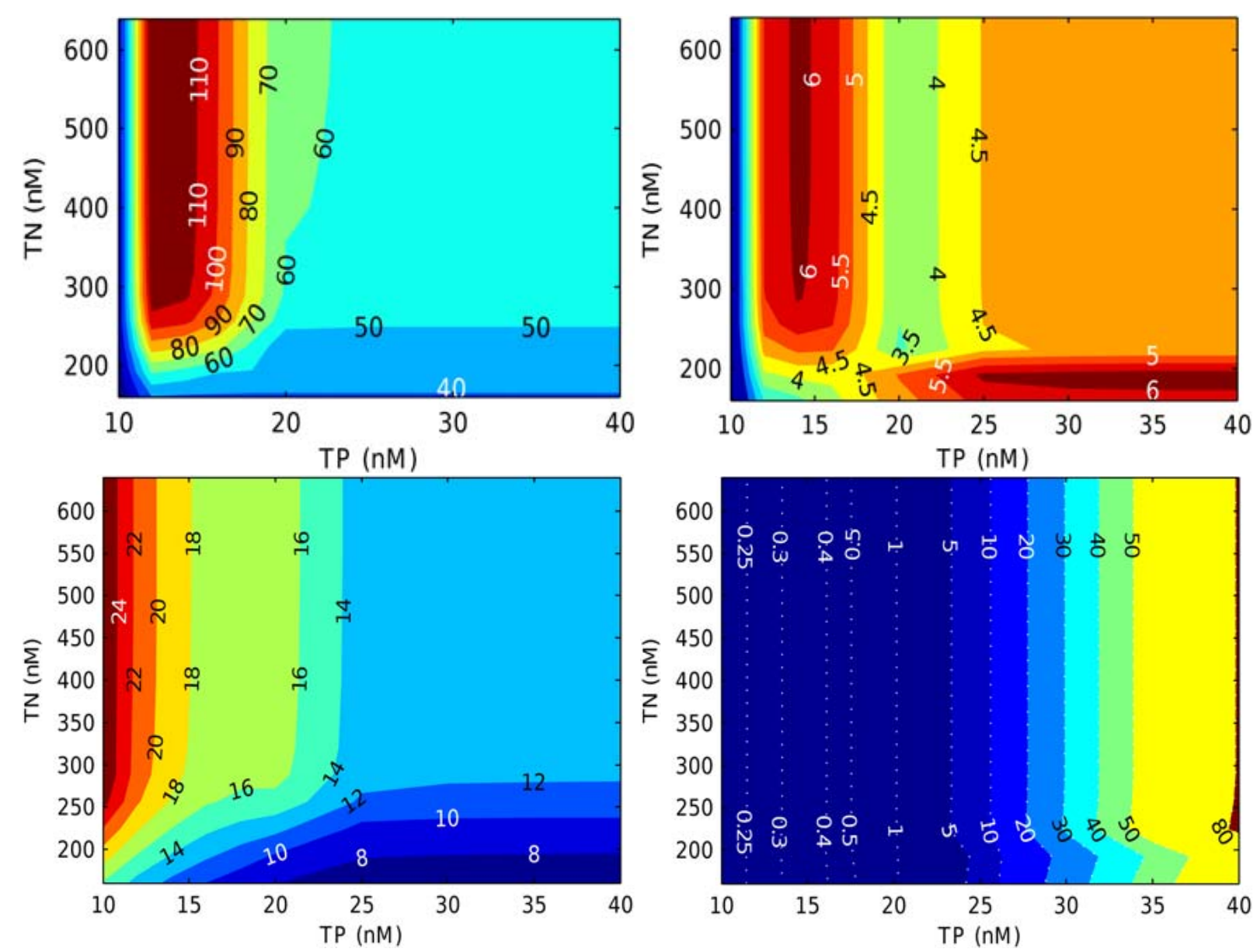

Fig. 5. Inorganic $\mathrm{N}$ (a) and $\mathrm{P}(\mathbf{b})$ uptake rate $\left(\mathrm{nmol} \mathrm{l}^{-1} \mathrm{~d}^{-1}\right)$, (c) $\mathrm{N}$ to $\mathrm{P}$ ratio of nutrient uptake and (d) inorganic phosphate turnover time $(h)$ as a function of TN and TP. 

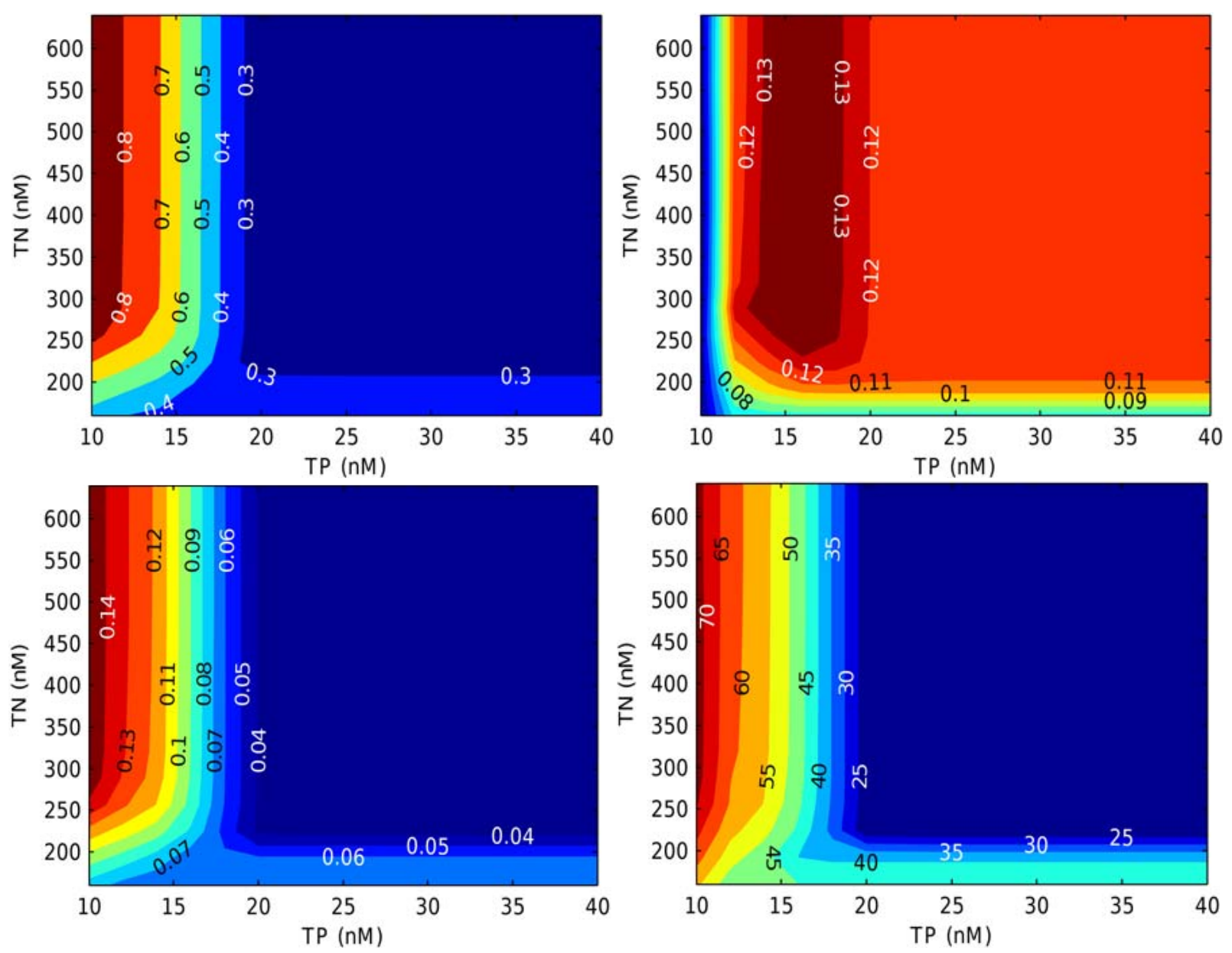

Fig. 6. Gross primary production (GPP), Net primary production (NPP), Chlorophyll concentration and photosynthetic extracellular released (PER) as a function of TN and TP.

the wide range of $\mathrm{N}: \mathrm{P}$ ratio associated with a given $\mathrm{P}$ uptake rate (Fig. 5c). Globally, the N:P ratio for nutrient uptake predicted by the model ranges from 6 to 24 and generally increases with increasing TN:TP ratio (Fig. 3a and Fig. 5c).

\subsection{Carbon Budget: Primary Production vs. Bacterial Production}

From the producers end (i.e. phytoplankton), gross primary production range from 0.3 to $0.9 \mu \mathrm{mol} \mathrm{l}^{-1} \mathrm{~d}^{-1}$ (Fig. 6a). The highest rate for GPP is found for low TP values (where phytoplankton growth is P-limited) and TN values above $250 \mathrm{nM}$. This increase in GPP with decreasing P availability is counter-intuitive and is mainly the results of the higher chlorophyll content found in this type of simulation (Fig. 6c). In fact, when growth is P-limited and when inorganic $\mathrm{N}$ is abundant, nitrogen cell content of phytoplankton increases until it reaches $Q_{N}^{\max }$. Since maximum chlorophyll content is scaled to the $\mathrm{N}$ content of the cell, Chlorophyll concentration is maximum and so is GPP. However due to the P-limitation of phytoplankton growth under low $\mathrm{P}$ environment, most of the carbon fixed during gross primary production is exuded as DOC (Fig. 6d) and fuelled the BCD (Fig. 7a) or accumulate as DOC (Fig. 8). In our model, phytoplankton exudation range from 21 to $72 \%$ of GPP and it increases with increasing oligotrophy. The balance between GPP, exudation and respiration of storage compounds results in a net primary production rate ranging from 0.015 to $0.12 \mu \mathrm{molCl}^{-1} \mathrm{~d}^{-1}$ (Fig. 6b). Net primary production in the model is equivalent to the specific growth rate $\left(h^{-1}\right)$ of phytoplankton multiply by its carbon biomass. Thus increase in NPP is either the result of an increasing specific growth rate or of an increasing carbon intracellular content both of which tend to behave in opposite way. For example, under nutrient limited environment growth is limited by nutrients and growth rate decreases but, at the same time, carbon accumulates in the cell increasing the carbon biomass of the phytoplankton compartment. Thus similar net primary production rate could be found for different specific growth rate assuming that they are associated with different carbon intracellular content. From the consumers end (e.g. bacteria), the bacterial carbon demand (BCD) represent the total amount of 

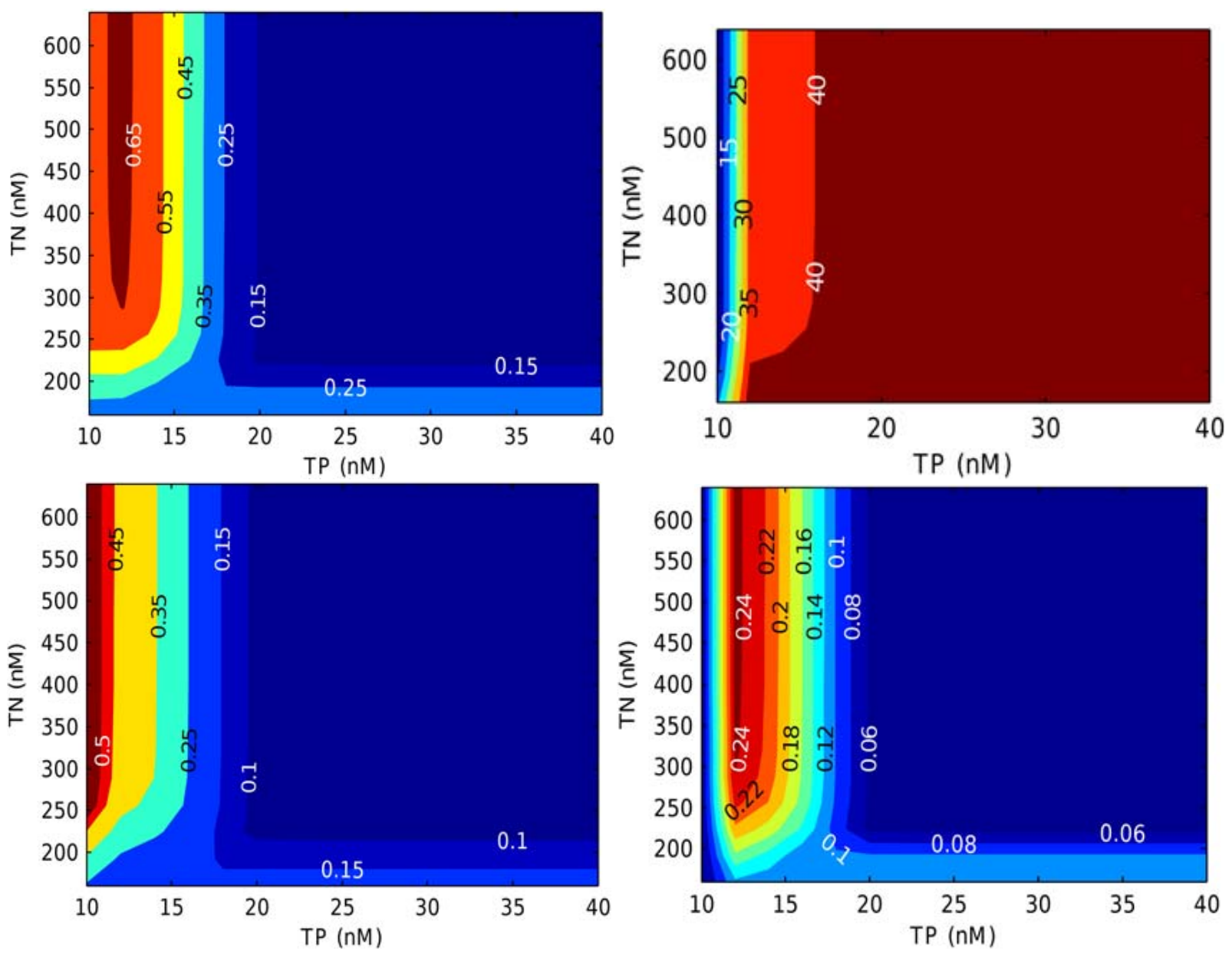

Fig. 7. Bacterial carbon demand (BCD), bacterial growth efficiency (BGE), Bacterial respiration rate (BR) and Bacterial production (BP) as a function of $\mathrm{TN}$ and $\mathrm{TP}$.

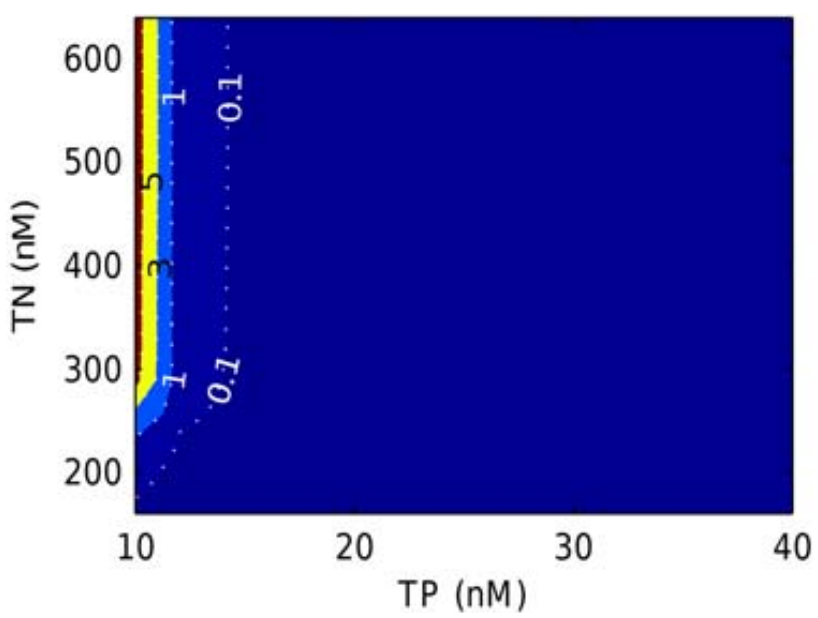

Fig. 8. Dissolved organic carbon concentrations in $\mu \mathrm{M}$ after 100 days of simulation as a function of TN and TP.
DOC taken up by heterotrophic bacteria prior to respiration and ranges from 0.13 to $0.67 \mu \mathrm{moll}^{-1} \mathrm{~d}^{-1}$ (Fig. 7a). The amount of carbon respired integrates respiration of stored compounds as well as respiration due to change in DOC quality (Fig. 7c) and range from 0.1 to $0.55 \mu \mathrm{moll}^{-1} \mathrm{~d}^{-1}$. The bacterial growth efficiency $\left(\mathrm{BGE}=\frac{\mathrm{BP}}{\mathrm{BR}+\mathrm{BP}}\right)$ ranges between 0 and $41 \%$ (Fig. 7b). BGE decreases with increasing oligotrophy and this is the result of an increase of bacterial respiration which is more important than the increase in bacterial production. For example, over the same range of TP values from 16 to $12 \mathrm{nM}$ and for similar TN values $(480 \mathrm{nM}), \mathrm{BP}$ increase from $0.16 \mu \mathrm{mol}^{-1} \mathrm{~d}^{-1}(\mathrm{TP}=16 \mathrm{nM})$ to $0.24 \mu \mathrm{moll}^{-1} \mathrm{~d}^{-1}(\mathrm{TP}=12 \mathrm{nM})$ while bacterial respiration increases from $0.24 \mu \mathrm{moll}^{-1} \mathrm{~d}^{-1}$ to $0.42 \mu \mathrm{moll}^{-1} \mathrm{~d}^{-1}$ over the same range. Thus while BP increased by $50 \%$, BR increases by $75 \%$ resulting in a overall decrease in BGE of about $10 \%$. Under even lower TP concentrations, BP start to decrease while BR continue to increase resulting in an even lower BGE. However, BGE is only sensitive to nutrient limitation and seems more correlated to nutrient availability than to carbon availability. If we consider bacterial production 
(BP) which was assumed to be the growth rate of the organisms multiply by its carbon content, values range between 0.05 to $0.25 \mu \mathrm{mol}^{-1} \mathrm{~d}^{-1}$ (Fig. 7). The overall results of the balance between carbon production and carbon respiration is the possible accumulation of DOC in the model. For most of our simulations, DOC does not accumulate and displays values close to zero which is consistent with the idea of balance carbon budget during the summer period. However in the case of low TP values and high TN values, the model predicts a net production of DOC which results in the accumulation $5 \mu \mathrm{M}$ of DOC within the hundred days of our simulations. This result is of particular interest and highlight the accumulation of more carbon under high $\mathrm{N}: \mathrm{P}$ ratio compare to balance $(16: 1)$ or low $\mathrm{N}: \mathrm{P}$ ratio. To which extent this result is relevant when trying to understand the accumulation of DOC in the surface layer of the Mediterranean Sea is discussed in the next section.

\section{Discussion}

In the surface layer of the ocean, understanding the interaction between heterotrophic bacteria and phytoplankton is a complex issue that involves competition in terms of inorganic nutrients and commensalism in terms of carbon. While some authors have focused on the competition for inorganic nutrients (Thingstad et al., 1997; Thingstad, 2005), others have focused on the balance between primary production and respiration (Anderson and Ducklow, 2001; Anderson and Turley, 2003). However, to our knowledge, none have tried to tackle both issues at the same time using a simple model such as the one describe in this study. Combining a C-based model with a nutrient based model requires a framework in which all three elements can be coupled in a coherent manner. The use of cellular abundances and variable intracellular elemental contents combined with a Droop-like approach for growth appears as a relatively simple and straightforward description that allows the coupling of carbon and nutrients in living population using relatively realistic constraints. At the cell level, clear constraints in terms of biomass (using maximum and minimum intracellular contents) and in terms of nutrient uptake (using size considerations and diffusion limitations) are very useful for the calibration of a model. Although this study is not a validation of the model in a strict sense, we can notice that the overall range of values displayed by the model, in term of $\mathrm{N}$ and $\mathrm{P}$, are consistent with published data for the Mediterranean Sea. For inorganic phosphate, due to the quantification limit of commonly used measurement techniques $(50 \mathrm{nM})$, it is difficult to assess whether or not the concentrations displayed by the model are reasonable. Nonetheless, in the literature, inorganic phosphate concentrations at the surface was suggested to lie somewhere between 0.1 and $5 \mathrm{nM}$ during summer and the associated turnover times are of the order of a few hours (Thingstad et al., 1996; Moutin et al., 2002). These findings are reason- ably close to our model values for phosphate (Fig. 3b and 5d). Since the Mediterranean Sea is assume to be P-limited, few study have focus on the dynamic of the non-limiting elements such as inorganic nitrogen. In contrast to inorganic phosphate concentrations, a substantial amount of inorganic nitrogen can remain at the surface, especially in the eastern basin (Krom et al., 1992). The main consequence is that, in the surface layer, high $\mathrm{N}: \mathrm{P}$ ratio could be expected and model results displaying more than $300 \mathrm{nM}$ of inorganic $\mathrm{N}$ with close to zero nM of $\mathrm{P}$ may not be unreasonable. In the Gulf of Lions (western basin), Diaz and Raimbault (2000) measured uptake rate $\left(\mathrm{NH}_{4}^{+}+\mathrm{NO}_{3}^{-}\right)$close to our values, ranging from 50 to $100 \mathrm{nmol}^{-1} \mathrm{~d}^{-1}$ at the onset of the stratified period. Looking at our model results for $\mathrm{N}$ and $\mathrm{P}$ uptake (Figs. 5a and 5b), our size assumption combined with the cellular abundance selected for our simulations seems to give a satisfying first approximation of the expected nutrient fluxes for the western basin at least. Concerning cellular growth rate, values are in the range of reported values for osmotrophs in the oceans (Duhamel et al., 2007). Although the estimation of osmotrophs growth rate in oceanic environment is still subject to debate, it has been suggested that phytoplankton growth rate are well below their maximum growth rates and that values below $0.5 \mathrm{~d}^{-1}$ are consistent with the existing knowledge on the relationship between elemental composition and physiological state in phytoplankton (Maranon, 2005). Our model seems to concur with such hypotheses at least for small phytoplankton in oligotrophic environment. In terms of growth limitation, model results are also quite consistent with what has been reported in the literature based on bioassay experiments. For heterotrophic bacteria, positive response to $\mathrm{P}$ and $\mathrm{C}$ enrichments were observed (Wambeke et al., 2002), and for pico-phytoplankton enrichment experiments show either P-limitation or NP-colimitation (Thingstad et al., 1998, 2005; Tanaka et al., 2010). However in our model, growth limitation by phosphate of both osmotrophic groups is restricted to extremely low concentrations $(<0.12 \mathrm{nM})$ and resulted from the relatively high affinity used in the model for bacteria $\left(0.51 \mathrm{nmol}^{-1} \mathrm{~h}^{-1}\right)$ and phytoplankton $\left(0.331 \mathrm{nmol}^{-1} \mathrm{~h}^{-1}\right)$ compared to in situ data (0.16 to $0.21 \mathrm{nmol}^{-1} \mathrm{~h}^{-1}$ (Moutin et al., 2002)). To reduce the maximum affinity in our model, one could consider an increase of the half saturation constant $\left(K_{X}\right)$, an increase in the minimum intracellular $\mathrm{P}$ content $\left(Q_{\min }^{P}\right)$ or a decrease in the maximum uptake rate $V_{X}^{\max }$. Yet, any modification of these parameters will be constrained by size considerations since increasing $\mathrm{P}$ requirement will increase the amount of phosphate per unit of cell volume and decreasing $V^{\max }$, or increasing $K_{X}$, will imply a smaller size (Eq. 20) which in turn induces an increase in element concentrations per unit of cell volume. For nitrogen, the picture is more complicated. Although phytoplankton cells display N-limitation for inorganic $\mathrm{N}$ concentrations below $2 \mathrm{nM}$, in the same environment, heterotrophic bacteria are $\mathrm{C}$-limited. This feature is 
mainly the result of the strong coupling between nitrogen and carbon in phytoplankton cells which restricts the production of bioavailable carbon for heterotrophic bacteria under Nlimited conditions. In general, the interaction between bacteria and phytoplankton from a carbon point of view is more complex than from a nutrient point of view. Quantitatively, model results are quite close to published data concerning the carbon dynamic in the Mediterranean sea. In the western basin, primary production rate range between 0.1 and $0.6 \mu \mathrm{moll}^{-1} \mathrm{~d}^{-1}$ (Moutin and Raimbault, 2002; Lemee et al., 2002). Directly comparing in situ primary production with our model results is quite complicated since ${ }^{14} \mathrm{C}$ based primary production is neither a gross production rate nor a net production rate. In fact, Moutin et al. (1999) have proposed a model and estimated gross primary production to be:

$\mathrm{GPP}=1.72 A_{N}^{*}$

where $A_{N}^{*}$ is the daily primary production ( $24 \mathrm{~h}$ dawn-todawn) rate measured with the ${ }^{14} \mathrm{C}$ method. With this approach, our gross primary production in the model is within the range of the previously cited studies. Concerning P.E.R., the values displayed by the model may appear high, especially in extremely low $\mathrm{P}$ environment where it can reach up to $72 \%$ of GPP. The modelled values are much higher than the typical 16 to $30 \%$ of PER measured for the Mediterranean Sea (Moran et al., 2002; Lopez-Sandoval et al., 2010). On the other hand, in a control mesocosm environment using Adriatic sea water, Fajon et al. (1999) reported values for P.E.R. as high as $80 \%$. Thus it is difficult to assess to which extent our values of PER are unreasonable. In order to reduce the fraction of GPP exuded as P.E.R, the quota function (Eq. 17) could be modify to:

$f^{Q_{X}}=\left(\frac{Q_{X}^{\max }-Q_{X}}{Q_{X}^{\max }-Q_{X}^{\min }}\right)^{n}$

Using $n$ values lower than 1 in Eq. (29) would tend to decrease exudation rate when carbon content approaches $Q_{C}^{\min }$ but this in turn would decrease DOC availability for heterotrophic bacteria and may narrow the range of nutrient concentrations for which bacteria are nutrient limited. For this reason, and to avoid a loss of clarity in the model results due to the more complex form of the quota function, we did not include such description in the current model. Concerning the BP and BGE in the model, values are also quite close to expected values for the Mediterranean Sea. In the western basin, bacterial production range from 0.05 to $0.2 \mu \mathrm{mol}^{-1} \mathrm{~d}^{-1}$ (Wambeke et al., 2002; Lemee et al., 2002). Although BP measurements using the assimilation of radiolabeled amino acids should be considered carefully when compared to model results, it seems that the model is relatively close to experimental values. In a review, del Giorgio and Cole (1998) estimated BGE to vary between less than 0.05 to as high as 0.6 , with a systematic decrease with increasing oligotrophy. BGE in the model does decrease with decreasing nutrient availability and the range between 0.15 and 0.4 is reasonable given the large uncertainties associated with BGE measurements. From a more qualitative point of view, an interesting aspect of the model is its ability to reproduce the higher P.E.R. in P-limited system compared to N-limited system (Obernosterer and Herndl, 1995). This is a significant aspect that is not always taken into account when one wants to explain the particularly high DOC concentration in the surface layer of the Mediterranean Sea. While some authors have suggested that P-limitation of heterotrophic bacteria could cause and accumulation of DOC during summer (Thingstad et al., 1997), other have used refractorization of DOC to explain the observed accumulation (Polimene et al., 2006) but differences may also arise from the producing end (Cauwet et al., 2002). We propose in this model a possible mechanism to explain the high DOC production under high N:P ratio. In our model, chlorophyll synthesis is not influenced by the $\mathrm{P}$ status of the cell but in contrast it is proportional to the $\mathrm{N}$ content of the phytoplankton cells. This was motivated by the fact that under $\mathrm{N}-$ limited conditions authors have shown a bleaching of phytoplankton cells as a result of decreasing chlorophyll content (Schwarz and Forchhammer, 2005). High N:P environment combined with P-limitation of phytoplankton growth increase the uncoupling between GPP and growth and thus increase P.E.R. This implies a complex system where both source of bioavailable carbon (P.E.R. and mortality) display opposite trends. If we consider phytoplankton, when growth is severely limited by the availability of phosphate and when $\mathrm{N}$ is abundant, DOC production through exudation is maximum and represents almost all the carbon available for heteotrophic bacteria. When $\mathrm{N}$ and $\mathrm{P}$ are abundant DOC production through mortality increases with increasing growth rate but on the other hand, photosynthetic extracellular release decreases rapidly. It implies that heterotrophic bacteria may benefit from slow growing nutrient limited phytoplankton with high exudation rates, especially if we consider them more competitive for nutrients and if we assume P.E.R to be a reliable source of DOC for heterotrophic bacteria. Another consequence is the more direct coupling between primary production and bacterial production under P-limited conditions, a feature that has been shown experimentally when comparing the eastern and the western basin (Turley et al., 2000).

Although model results could be improved especially concerning carbon dynamics, overall results are quite consistent with our current knowledge of the carbon cycle in the surface layer of the Mediterranean sea. In addition, our study of a steady state system gives us clear indication on the process that are responsible for the observed DOC accumulation in the surface layer of the Mediterranean Sea. First, based on the low values of DOC concentrations at steady state, our model suggest that DOC accumulation is probably not a continuous process and that during the stratified period, it is more likely that the system is balanced or net 
heterotrophic. However, the DOC accumulation observed under extremely low $\mathrm{P}$ concentrations suggest that the combination of high PER and P-limited growth may explain the high DOC concentration observed at the surface layer of the Mediterranean Sea during summer. High PER could arise due to the unusual N:P ratio found in the Mediterranean Sea. The fact that DOC concentration at surface of the ocean increases between the Atlantic ocean and the western Mediterranean basin (Aminot and Kerouel, 2004) and between the western and the eastern Mediterranean basin; and the fact that along the same transect, the N:P ratio increases from 16:1 for the Atlantic ocean to more than $28: 1$ for the eastern Mediterranean basin (Pujo-Pay et al., 2010), may suggest that the role of the N:P ratio on DOC accumulation in the model is somehow representative of what is occurring on seasonal time scales (eventhough our model intend to represent mechanisms occurring on shorter time scales). In fact, one should keep in mind that the trend we have described here would be even more pronounced if one takes into account the uncoupling of bacterial and phytoplankton biomass during the spring bloom, due to stronger grazing pressure on heterotrophic bacteria. In other word, DOC accumulation in our simulations would be much greater if bacterial cell number is kept constant while phytoplankton cell number goes up.

This control of osmotrophs population by predation is usually refered as the top down control. As we have stated earlier, our study focused on the bottom up control of organisms growth and its potential effect on DOC accumulation and this was acheived by assuming constant cell populations. In our model, top down effect on DOC accumulation was considered implicitly for carbon by re-routing $50 \%$ of the carbon lost through mortality into the DOC pool. Our steady state assumptions allow us to disregard predator biomass. However, in a dynamical model, it is imperative to consider explicit population of predators as part of the $\mathrm{N}$ and $\mathrm{P}$ would be channelled into predator biomass and would remain unavailable to osmotrophs (Thingstad and Rassoulzadegan, 1999). However, considering zooplankton explicitly also required detailed knowledge on their growth rate and stoichiometry. Although we did find an exhaustive literature on the C, N and $\mathrm{P}$ content of osmotrophs, very few data are available for higher trophic level such as heterotrophic nano-flagellates (Menden-Deuer and Lessard, 2000). This knowledge of predator stoichiomerty is a key issue that has been discussed before (Vanni and Layne, 1997). For example in the case where $\mathrm{N}: \mathrm{P}$ in phytoplankton is higher than the $\mathrm{N}: \mathrm{P}$ ratio in their predators, this would result in preferential $\mathrm{N}$ remineralization leading to P-limitation whereas a lower $\mathrm{N}: \mathrm{P}$ ratio in predator biomass would result in preferential $\mathrm{P}$ remineralization leading to a N-limited system. With this in mind, further work on predators stoichiometry appear as a key aspect that would help understand the potential effect of predator biomasses and stoichiometry on the overall $\mathrm{C}, \mathrm{N}, \mathrm{P}$ coupling observed in the surface waters of the Mediterranean Sea.

\section{Conclusion}

In our study, we focused on the surface layer of the Mediterranean Sea. In summer, this system is characterized by low nutrient concentrations, relatively stable populations of phytoplankton and heterotrophic bacteria and high DOC concentrations. The interactions between phytoplankton and heterotrophic bacteria are characterized by strong competition for nutrients and commensalism for carbon. To better understand the balance between growth and carbon production/consumption, we implemented in Eco3M a multielement, mechanistic model with cell abundances as an explicit variable. With this model, we compared different steady state regimes obtained under various amount of inorganic nitrogen and phosphate. We verified that the magnitude of the different stocks and fluxes displayed by the model were in agreement with the in-situ data found in the literature for the Mediterranean Sea. This approach allows us to determine the conditions for which osmotrophs may be nutrient limited rather than energy (carbon) limited. In addition, the model gave us insight on the primary production rate, DOC exudation and bacterial growth efficiency expected under steady state regimes. Last but not least, the model displayed significant differences between $\mathrm{N}$ and $\mathrm{P}$ limited systems and we used these results to explain how DOC accumulation in the surface layer of the ocean may be a characteristic of P-limited systems and how the balance between chlorophyll production and growth could explain the high exudation rate observed under low $\mathrm{P}$ and high $\mathrm{N}$ environment.

Acknowledgements. This is a contribution of the BOUM (Biogeochemistry from the Oligotrophic to the Ultraoligotrophic Mediterranean) experiment (http://www.com.univ-mrs.fr/BOUM) of the french national LEFE-CYBER program, the european IP SESAME and the international IMBER project. The BOUM experiment was coordinated by the Institut des Sciences de l'Univers (INSU) and managed by the Centre National de la Recherche Scientifique (CNRS).

Edited by: C. Jeanthon

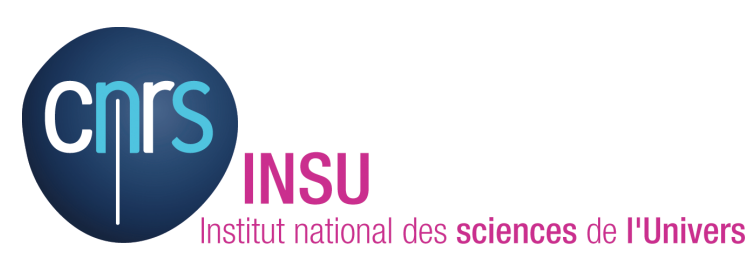

The publication of this article is financed by CNRS-INSU. 


\section{References}

Aminot, A. and Kerouel, R.: Dissolved organic carbon, nitrogen and phosphorus in the N-E Atlantic and the N-W Mediterranean with particular reference to non-refractory fractions and degradation, Deep-Sea Res. Pt. I, 51, 1975-1999, 2004.

Anderson, T. R. and Ducklow, H. W.: Microbial loop carbon cycling in ocean environments studied using a simple steady-state model, Aquat. Microb. Ecol., 26, 37-49, 2001.

Anderson, T. R. and Turley, C. M.: Low bacterial growth efficiency in the oligotrophic eastern Mediterranean Sea: a modelling analysis, J. Plankton Res., 25, 1011-1019, 2003.

Baklouti, M., Diaz, F., Pinazo, C., Faure, V., and Quguiner, B.: Investigation of mechanistic formulations depicting phytoplankton dynamics for models of marine pelagic ecosystems and description of a new model, Prog. Oceanogr., 71, 1-33, 2006a.

Baklouti, M., Faure, V., Pawlowski, L., and Sciandra, A.: Investigation and sensitivity analysis of a mechanistic phytoplankton model implemented in a new modular numerical tool (Eco3M) dedicated to biogeochemical modelling, Prog. Oceanogr., 71, 34-58, 2006b.

Bertilsson, S., Berglund, O., Karl, D. M., and Chisholm, S. W.: Elemental composition of marine Prochlorococcus and Synechococcus: Implications for the ecological stoichiometry of the sea, Limnol. Oceanogr., 48, 1721-1731, 2003.

Bjornsen, P. K.: Phytoplankton Exudation of Organic Matter: Why Do Healthy Cells Do It?, Limnol. Oceanogr., 33, 151-154, 1988.

Bronk, D. A., See, J. H., Bradley, P., and Killberg, L.: DON as a source of bioavailable nitrogen for phytoplankton, Biogeosciences, 4, 283-296, doi:10.5194/bg-4-283-2007, 2007.

Cauwet, G., Deliat, G., Krastev, A., Shtereva, G., Becquevort, S., Lancelot, C., Momzikoff, A., Saliot, A., Cociasu, A., and Popa, L.: Seasonal DOC accumulation in the Black Sea: a regional explanation for a general mechanism, Mar. Chem., 79, 193-205, 2002.

Christaki, U., Giannakourou, A., Van Wambeke, F., and Gregori, G.: Nanoflagellate predation on auto- and heterotrophic picoplankton in the oligotrophic Mediterranean Sea, J. Plankton Res., 23, 1297-1310, 2001.

Christaki, U., Courties, C., Karayanni, H., Giannakourou, A., Maravelias, C., Kormas, K. A., and Lebaron, P.: Dynamic characteristics of Prochlorococcus and Synechococcus consumption by bacterivorous nanoflagellates, Microb. Ecol., 43, 341-352, 2002.

Claustre, H., Babin, M., Merien, D., Ras, J., Prieur, L., Dallot, S., Prasil, O., Dousova, H., and Moutin, T.: Toward a taxon-specific parameterization of bio-optical models of primary production: A case study in the North Atlantic, J. Geophys. Res., 110, 1-17, C07S12, 2005.

del Giorgio, P. A. and Cole, J. J.: Bacterial Growth Efficiency in Natural Aquatic Systems, Annu. Rev. Ecol. Syst., 29, 503-541, 1998.

Diaz, F. and Raimbault, P.: Nitrogen regeneration and dissolved organic nitrogen release during spring in a NW Mediterranean coastal zone (Gulf of Lions): implications for the estimation of new production, Mar. Ecol.-Prog. Ser., 197, 51-65, 2000.

Drakare, S.: Competition between Picoplanktonic Cyanobacteria and Heterotrophic Bacteria along Crossed Gradients of Glucose and Phosphate, Microb. Ecol., 44, 327-335, 2002.

Droop, M. R.: Vitamin B12 and Marine Ecology. IV. The Kinetics of Uptake, Growth and Inhibition in Monochrysis Lutheri, J.
Mar. Biol. Assoc. UK, 48, 689-733, 1968.

Duhamel, S., Moutin, T., Van Wambeke, F., Van Mooy, B., Rimmelin, P., Raimbault, P., and Claustre, H.: Growth and specific Puptake rates of bacterial and phytoplanktonic communities in the Southeast Pacific (BIOSOPE cruise), Biogeosciences, 4, 941956, doi:10.5194/bg-4-941-2007, 2007.

Fagerbakke, K. M., Heldal, M., and Norland, S.: Content of carbon, nitrogen, oxygen, sulfur and phosphorus in native aquatic and cultured bacteria, Aquatic Microb. Ecol., 10, 15-27, 1996.

Fajon, C., Cauwet, G., Lebaron, P., Terzic, S., Ahel, M., Malej, A., Mozetic, P., and Turk, V.: The accumulation and release of polysaccharides by planktonic cells and the subsequent bacterial response during a controlled experiment, Fems Microbiol. Ecol., 29, 351-363, 1999.

Fu, F. X., Zhang, Y. H., Feng, Y. Y., and Hutchins, D. A.: Phosphate and ATP uptake and growth kinetics in axenic cultures of the cyanobacterium Synechococcus CCMP 1334, Eur. J. Phycol., 41 15-28, 2006

Fukuda, R., Ogawa, H., Nagata, T., and Koike, I.: Direct determination of carbon and nitrogen contents of natural bacterial assemblages in marine environments, Appl. Environ. Microb., 64, 3352-3358, 1998.

Goldman, J. and McCarthy, J.: Steady State Growth and Ammonium Uptake of a Fast-Growing Marine Diatom, Limnol. Oceanogr., 23, 695-703, 1978.

Grover, J. P.: Resource competition and community structure in aquatic micro-organisms: experimental studies of algae and bacteria along a gradient of organic carbon to inorganic phosphorus supply, J. Plankton Res., 22, 1591-1610, 2000.

Gundersen, K., Heldal, M., Norland, S., Purdie, D. A., and Knap, A. H.: Elemental $\mathrm{C}, \mathrm{N}$, and $\mathrm{P}$ cell content of individual bacteria collected at the Bermuda Atlantic Time-Series Study (BATS) site, Limnol. Oceanogr., 47, 1525-1530, 2002.

Hagstrom, A., Azam, F., Andersson, A., Wikner, J., and Rassoulzadegan, F.: Microbial Loop In An Oligotrophic Pelagic Marine Ecosystem - Possible Roles Of Cyanobacteria And Nanoflagellates In The Organic Fluxes, Mar. Ecol.-Prog. Ser., 49, 171-178, 1988.

Han, B. P.: A Mechanistic Model of Algal Photoinhibition Induced by Photodamage to Photosystem-II, J. Theor. Biol., 214, 519527, 2002.

Healey, F. P.: Slope of the Monod equation as an indicator of advantage in nutrient competition, Microb. Ecol., 5, 281-286, 1980.

Heldal, M., Scanlan, D. J., Norland, S., Thingstad, F., and Mann, N. H.: Elemental composition of single cells of various strains of marine Prochlorococcus and Synechococcus using X-ray microanalysis, Limnol. Oceanogr., 48, 1732-1743, 2003.

Ikeya, T., Ohki, K., Takahashi, M., and Fujita, Y.: Study on phosphate uptake of the marine cyanophyte Synechococcus sp NIBB 1071 in relation to oligotrophic environments in the open ocean, Mar. Biol., 129, 195-202, 1997.

Joint, I., Henriksen, P., Fonnes, G. A., Bourne, D., Thingstad, T. F., and Riemann, B.: Competition for inorganic nutrients between phytoplankton and bacterioplankton in nutrient manipulated mesocosms, Aquat. Microb. Ecol., 29, 145-159, 2002.

Kirchman, D. L.: The uptake of inorganic nutrients by heterotrophic bacteria, Microb. Ecol., 28, 255-271, 1994.

Klausmeier, C., Litchman, E., Daufresne, T., and Levin, S.: Phytoplankton stoichiometry, Ecol. Res., 23, 479-485, 2008. 
Krom, M. D., Kress, N., Brenner, S., and Gordon, L. I.: Phosphorus Limitation of Primary Productivity in the Eastern Mediterranean Sea, Limnol. Oceanogr., 36, 424-432, 1991.

Krom, M. D., Brenner, S., Kress, N., Neori, A., and Gordon, L. I.: Nutrient Dynamics And New Production In A Warm-Core Eddy From The Eastern Mediterranean-Sea, Deep-Sea Res., 39, 467480, 1992.

Lehman, J., Daniel B. Botkin, D., and Likens, G.: The Assumptions and Rationales of a Computer Model of Phytoplankton Population Dynamics, Limnol. Oceanogr., 20, 343-364, 1975.

Lemee, R., Rochelle-Newall, E., Van Wambeke, F., Pizay, M. D., Rinaldi, P., and Gattuso, J. P.: Seasonal variation of bacterial production, respiration and growth efficiency in the open NW Mediterranean Sea, Aquat. Microb. Ecol., 29, 227-237, 2002.

López-Sandoval, D. C., Fernández, A., and Marañón, E.: Dissolved and particulate primary production along a longitudinal gradient in the Mediterranean Sea, Biogeosciences Discuss., 7, 85918617, doi:10.5194/bgd-7-8591-2010, 2010.

Lovdal, T.: Competition between marine osmotrophs for phosphorus and nitrogen: implications for the microplanktonic food web, Ph.D. thesis, The University of Bergen, 2007.

Lovdal, T., Skjoldal, E. F., Heldal, M., Norland, S., and Thingstad, T. F.: Changes in morphology and elemental composition of Vibrio splendidus along a gradient from carbon-limited to phosphate-limited growth, Microb. Ecol., 55, 152-161, 2008.

Mauriac, R.: Observation et modelisation du couplage/decouplage du cycle du carbone et des elements biogenes associes en zone eclairee en Mediterranee, Centre d'Oceanologie de Marseille (Universite de Aix Marseille II), 2011.

Mauriac, R., and Moutin, T., and Baklouti, M.: Elemental content and elemental ratio among marine osmotrophs: Should heterotrophic bacteria and phytoplankton be considered different in biogeochemical model?, 2011.

Magazzu, G. and Decembrini, F.: Primary production, biomass and abundance of phototrophic picoplankton in the Mediterranean Sea: a review, Aquat. Microb. Ecol., 09, 97-104, 1995.

Maranon, E.: Phytoplankton growth rates in the Atlantic subtropical gyres, Limnol. Oceanogr., 50, 299-310, 2005.

Menden-Deuer, S. and Lessard, E. J.: Carbon to Volume Relationships for Dinoflagellates, Diatoms, and Other Protist Plankton, Limnol. Oceanogr., 45, 569-579, 2000.

Middelboe, M. and Sondergaard, M.: Bacterioplankton Growth Yield: Seasonal Variations and Coupling to Substrate Lability and beta-Glucosidase Activity, Appl. Environ. Microbiol., 59, 3916-3921, 1993.

Moran, X. A. G., Estrada, M., Gasol, J. M., and Pedros-Alio, C.: Dissolved primary production and the strength of phytoplankton bacterioplankton coupling in contrasting marine regions, Microb. Ecol., 44, 217-223, 2002.

Moutin, T. and Raimbault, P.: Primary production, carbon export and nutrients availability in western and eastern Mediterranean Sea in early summer 1996 (MINOS cruise), J. Mar. Syst., 33-34, 273-288, 2002.

Moutin, T., Raimbault, P., and Poggiale, J.-C.: Primary production in surface waters of the western Mediterranean sea. Calculation of daily production, Comptes Rendus de l'Acadmie des Sciences - Series III - Sciences de la Vie, 322, 651-659, 1999.

Moutin, T., Thingstad, T. F., Van Wambeke, F., Marie, D., Slawyk, G., Raimbault, P., and Claustre, H.: Does competition for nanomolar phosphate supply explain the predominance of the cyanobacterium Synechococcus?, Limnol. Oceanogr., 47, 15621567, 2002.

Moutin, T., Karl, D. M., Duhamel, S., Rimmelin, P., Raimbault, P., Van Mooy, B. A. S., and Claustre, H.: Phosphate availability and the ultimate control of new nitrogen input by nitrogen fixation in the tropical Pacific Ocean, Biogeosciences, 5, 95-109, doi:10.5194/bg-5-95-2008, 2008.

Myklestad, S.: Release of extracellular products by phytoplankton with special emphasis on polysaccharides, Sci. Total Environ., 165, 155-164, 1995.

Nimer, E., Schneiderman, R., and Maroudas, A.: Diffusion and partition of solutes in cartilage under static load, Biophys. Chem., 106, 125-146, 2003.

Obernosterer, I. and Herndl, G. J.: Phytoplankton Extracellular Release And Bacterial-Growth - Dependence On The Inorganic NP Ratio, Mar. Ecol.-Prog. Ser., 116, 247-257, 1995.

Pedros-Alio, C., Caldern-Paz, J.-I., Guixa-Boixereu, N., Estrada, M., and Gasol, J. M.: Bacterioplankton and phytoplankton biomass and production during summer stratification in the northwestern Mediterranean Sea, Deep Sea Res. Pt. I, 46, 985 1019, 1999.

Polimene, L., Allen, J. I., and Zavatarelli, M.: Model of interactions between dissolved organic carbon and bacteria in marine systems, Aquat. Microb. Ecol., 43, 127-138, 2006.

Pujo-Pay, M., Conan, P., Oriol, L., Cornet-Barthaux, V., Falco, C., Ghiglione, J.-F., Goyet, C., Moutin, T., and Prieur, L.: Integrated survey of elemental stoichiometry $(\mathrm{C}, \mathrm{N}, \mathrm{P})$ from the Western to Eastern Mediterranean Sea, Biogeosciences Discuss., 7, 73157358, doi:10.5194/bgd-7-7315-2010, 2010.

Riegman, R., Stolte, W., Noordeloos, A., and Slezak, D.: Nutrient uptake and alkaline phosphatase activity of emiliania huxleyi (PRYMNESIOPHYCEAE) during growth under N and P limitation in continuous cultures, J. Phycol., 36, 87-96, 2000.

Robarts, R. D., Zohary, T., Waiser, M. J., and Yacobi, Y. Z.: Bacterial abundance, biomass, and production in relation to phytoplankton biomass in the Levantine Basin of the southeastern Mediterranean Sea, Mar. Ecol.-Prog. Ser., 137, 273-281, 1996.

Schut, F., de Vries, E., Gottschal, J., Robertson, B., Harder, W., Prins, R., and Button, D.: Isolation of Typical Marine Bacteria by Dilution Culture: Growth, Maintenance, and Characteristics of Isolates under Laboratory Conditions, Appl. Environ. Microb., 2150-2160, 1993.

Schwarz, R. and Forchhammer, K.: Acclimation of unicellular cyanobacteria to macronutrient deficiency: emergence of a complex network of cellular responses, Microbiology-Sgm, 151, 2503-2514, 2005.

Siokou-Frangou, I., Christaki, U., Mazzocchi, M. G., Montresor, M., Ribera d'Alcalá, M., Vaqué, D., and Zingone, A.: Plankton in the open Mediterranean Sea: a review, Biogeosciences, 7, 1543-1586, doi:10.5194/bg-7-1543-2010, 2010.

Sondergaard, M. and Middelboe, M.: A Cross-System Analysis Of Labile Dissolved Organic-Carbon, Mar. Ecol.-Prog. Ser., 118, 283-294, 1995.

Tanaka, T. and Rassoulzadegan, F.: Full-depth profile (0-2000 m) of bacteria, heterotrophic nanoflagellates and ciliates in the NW Mediterranean Sea: Vertical partitioning of microbial trophic structures, Deep-Sea Res. Pt. II, 49, 2093-2107, 2002.

Tanaka, T. and Rassoulzadegan, F.: Vertical and seasonal variations 
of bacterial abundance and production in the mesopelagic layer of the NW Mediterranean Sea: bottom-up and top-down controls, Deep-Sea Res. Pt. I, 51, 531-544, 2004.

Tanaka, T., Thingstad, T. F., Christaki, U., Colombet, J., CornetBarthaux, V., Courties, C., Grattepanche, J.-D., Lagaria, A., Nedoma, J., Oriol, L., Psarra, S., Pujo-Pay, M., and Van Wambeke, F.: N-limited or $\mathrm{N}$ and $\mathrm{P}$ co-limited indications in the surface waters of three Mediterranean basins, Biogeosciences Discuss., 7, 8143-8176, doi:10.5194/bgd-7-8143-2010, 2010.

Terry, K. L., Laws, E. A., and Burns, D. J.: Growth-Rate Variation In The N-P Requirement Ratio Of Phytoplankton, J. Phycol., 21, 323-329, 1985.

Thingstad, T.: Simulating the response to phosphate additions in the oligotrophic eastern Mediterranean using an idealized fourmember microbial food web model, Deep Sea Res. Pt. II, 52, 3074-3089, 2005.

Thingstad, T. F.: Utilization Of N, P, And Organic C By Heterotrophic Bacteria. 1. Outline Of A Chemostat Theory With A Consistent Concept Of Maintenance Metabolism, Mar. Ecol.Prog. Ser., 35, 99-109, 1987.

Thingstad, T. F. and Rassoulzadegan, F.: Conceptual models for the biogeochemical role of the photic zone microbial food web, with particular reference to the Mediterranean Sea, Prog. Oceanogr., 44, 271-286, 1999.

Thingstad, T. F., Dolan, J. R., and Fuhrman, J. A.: Loss rate of an oligotrophic bacterial assemblage as measured by $\mathrm{H}$-3-thymidine and (PO4)-P-32: Good agreement and near-balance with production, Aquat. Microb. Ecol., 10, 29-36, 1996.

Thingstad, T. F., Hagstrom, A., and Rassoulzadegan, F.: Accumulation of degradable DOC in surface waters: Is it caused by a malfunctioning microbial loop?, Limnol. Oceanogr., 42, 398-404, 1997.

Thingstad, T. F., Zweifel, U. L., and Rassoulzadegan, F.: P limitation of heterotrophic bacteria and phytoplankton in the northwest Mediterranean, Limnol. Oceanogr., 43, 88-94, 1998.
Thingstad, T. F., Krom, M. D., Mantoura, R. F. C., Flaten, G. A. F., Groom, S., Herut, B., Kress, N., Law, C. S., Pasternak, A., Pitta, P., Psarra, S., Rassoulzadegan, F., Tanaka, T., Tselepides, A., Wassmann, P., Woodward, E. M. S., Riser, C. W., Zodiatis, G., and Zohary, T.: Nature of Phosphorus Limitation in the Ultraoligotrophic Eastern Mediterranean, Science, 309, 1068-1071, 2005.

Turley, C. M., Bianchi, M., Christaki, U., Conan, P., Harris, J. R. W., Psarra, S., Ruddy, G., Stutt, E. D., Tselepides, A., and Van Wambeke, F.: Relationship between primary producers and bacteria in an oligotrophic sea - the Mediterranean and biogeochemical implications, Mar. Ecol.-Prog. Ser., 193, 11-18, 2000.

Vanni, M. J. and Layne, C. D.: Nutrient recycling and herbivory as mechanisms in the top-down effect of fish on algae in lakes, Ecology, 78, 21-40, 1997.

Vaulot, D., LeBot, N., Marie, D., and Fukai, E.: Effect of Phosphorus on the Synechococcus Cell Cycle in Surface Mediterranean Waters during Summer, Appl. Environ. Microbiol., 62, 25272533, 1996.

Wambeke, F., Goutx, M., Striby, L., Sempere, R., and Vidussi, F.: Bacterial dynamics during the transition from spring bloom to oligotrophy in the northwestern Mediterranean Sea: relationships with particulate detritus and dissolved organic matter, Mar. Ecol.-Prog. Ser., 212, 89-105, 2001.

Wambeke, F., Christaki, U., Giannakourou, A., Moutin, T., and Souvemerzoglou, K.: Longitudinal and Vertical Trends of Bacterial Limitation by Phosphorus and Carbon in the Mediterranean Sea, Microb. Ecol., 43, 119-133, 2002.

Weger, H. G., Herzig, R., Falkowski, P. G., and Turpin, D. H.: Respiratory Losses In The Light In A Marine Diatom - Measurements By Short-Term Mass-Spectrometry, Limnol. Oceanogr., 34, 1153-1161, 1989.

Yentsch, C. and Vaccaro, R.: Phytoplankton Nitrogen in the Oceans, Limnol. Oceanogr., 3, 443-448, 1958.

Yuan-Hui, L. and Gregory, S.: Diffusion of ions in sea water and in deep-sea sediments, Geochim. Cosmochim. Ac., 38, 703-714, 1974. 